\title{
Polyurethane/Zinc Oxide (PU/ZnO) Composite-Synthesis, Protective Property and Application
}

\author{
Mohammad Mizanur Rahman
}

Center of Research Excellence in Corrosion, King Fahd University of Petroleum and Minerals, Dhahran 31261, Saudi Arabia; mrahman@kfupm.edu.sa; Tel.: +96-6138607210

Received: 23 June 2020; Accepted: 9 July 2020; Published: 11 July 2020

check for updates

\begin{abstract}
A polyurethane (PU) is a multifunctional polymer prepared by using more than two types of monomers. The unique properties of PU come from monomers, thus broadening the applicability of PU in many different sectors. The properties can be further improved by using many nanoparticles. Different metal oxides as nanoparticles are also widely used in PU materials. $\mathrm{ZnO}$ is a widely used inorganic metal oxide nanoparticle for improving polymer properties. In this review article, the techniques to prepare a $\mathrm{PU} / \mathrm{ZnO}$ composite are reviewed; the key protective properties, such as adhesive strength and self-healing, and applications of $\mathrm{PU} / \mathrm{ZnO}$ composites are also highlighted. This review also highlights the $\mathrm{PU} / \mathrm{ZnO}$ composite's current challenges and future prospects, which will help to broaden the composite practical application by preparing environmentally friendly composites.
\end{abstract}

Keywords: polyurethane; $\mathrm{ZnO}$; composite

\section{Introduction}

A polyurethane (PU) material is considered to be a multifunctional polymer that consists mainly of urethane/urea groups (see Figure 1). During the Second World War, Otto Bayer, a German scientist, first synthesized PU. Over time, the PU has been improved by many research groups worldwide. Currently, the PU is widely used in many different applications. The main applications are as coatings, paints, adhesives, biomaterials and foams [1-26].

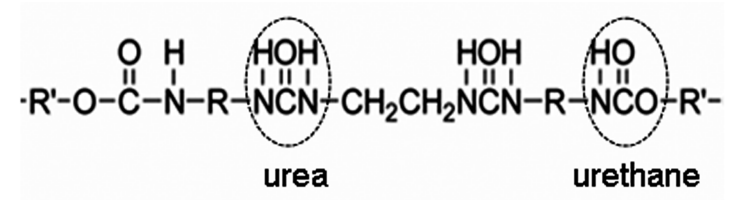

Figure 1. Urethane/urea group in polyurethane (PU).

The main monomers of the PU are polyol, isocyanate and small-molecular-weight amine/diol. The varieties of monomer choices, which have unique properties, make it easy to target specific applications. The properties such as mechanical strength, thermal stability, barrier resistance and adhesive strength are tuned by using different polyol, isocyanate and amine/diol monomers and their contents [1-5]. The properties were further tuned by using different nanoparticles, such as clay, CNT, metal oxide, hydroxyapatite and graphene [19-26]. Usually, the properties are at an unsatisfactory level when using unbalanced amounts (very low or very high content) of monomers and nanoparticles [27]. At the early stage, mainly petroleum-based toxic monomers were used in PU preparation. Recently renewable-resourced monomers, as well as less-toxic monomers, are also being used. Therefore, the $\mathrm{PU}$ is considered to be a less-toxic material $[1,2,18]$. 
The addition of different metal oxides as a nanoparticle into PU can enhance the material properties and broaden their applications. Widely used metal oxides are $\mathrm{ZnO}, \mathrm{CeO}_{2}, \mathrm{CuO}$ and $\mathrm{TiO}_{2}$ [26,28-40]. In the last two decades, a significant property improvement has been found by using the above metal oxides nanoparticles in the PU matrix. In particular, $\mathrm{ZnO}$ nanoparticle enhances the material properties and is being used in many different areas [31-84].

$\mathrm{ZnO}$ has unique properties, such as excellent photostability and chemical stability; furthermore, it has an electrochemical coupling coefficient and a broad range of radiation absorption [31-35]. Due to its low toxicity, biodegradability and biocompatibility, $\mathrm{ZnO}$ has been used with many polymers [81-85]. In many cases, $\mathrm{ZnO}$ was preferable to other metal oxides (such as $\mathrm{CeO}_{2}, \mathrm{CuO}$ and $\mathrm{TiO}_{2}$ ), because $\mathrm{ZnO}$ is comparatively very cost-effective, is free of surface water has and has an easy synthesis process $[34,37-41,50,62,64,86]$.

Many articles published in the last two decades highlight the application of a PU/ZnO composite [31-93]. Research is still ongoing by many research groups, and their intention is to find solutions for new challenges, using $\mathrm{PU} / \mathrm{ZnO}$ composites. However, there is no single review paper on the $\mathrm{PU} / \mathrm{ZnO}$ composite. It is important to summarize the work and identify unexplored areas. The main highlight of this article is the review of the preparation method of the composite and their key protective properties, the application of the composite and the future prospects of the PU/ZnO composite (see Figure 2). All the published papers [31-84] mention that the physical, thermal and mechanical properties improve when using a proper $\mathrm{ZnO}$ content in the $\mathrm{PU} / \mathrm{ZnO}$ composite; thus, the mentioned properties are not considered in this review article. However, the adhesion and self-healing properties of the $\mathrm{PU} / \mathrm{ZnO}$ composite are reviewed, because both are important parameters of protective application, and without sufficient adhesive strength, it is not possible to use any composite for any kind of application or protection. Self-healing can act as a repairing tool during the service time. As there are separate papers on basic polyurethane [1-3] and $\mathrm{ZnO}$ [81,94-98], the present article also does not highlight PU monomers, different $\mathrm{PU}$ or $\mathrm{ZnO}$ synthesis processes.

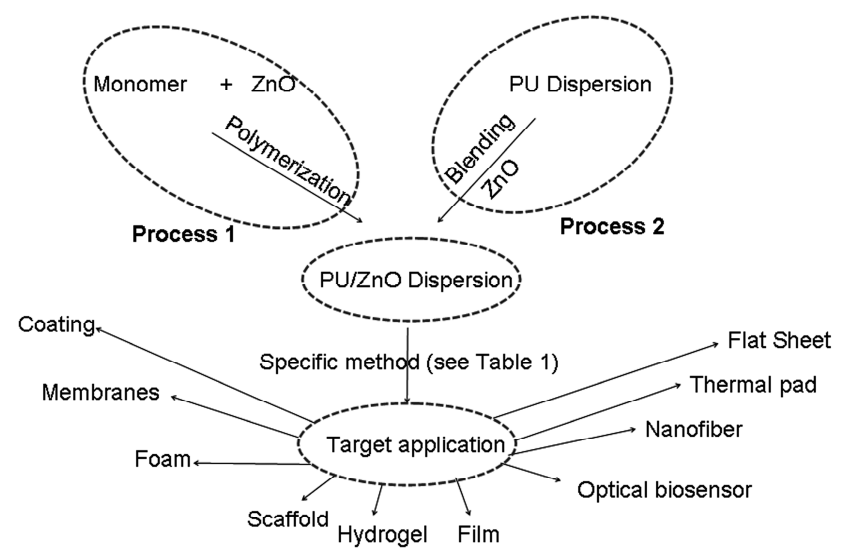

Figure 2. Preparation of $\mathrm{PU} / \mathrm{ZnO}$ composite and their application.

\section{Zinc Oxide Nanoparticles}

$\mathrm{ZnO}$ is an n-type metal-oxide, which has the band gap $3.37 \mathrm{Ev}$; thus, it exhibits excellent semiconducting properties. Recently, $\mathrm{ZnO}$ is being widely used in optics, electronics, coating, elastomer, sun-screen and biomedical applications [97-102]. There are different methods to ZnO synthesis which are available in many reports [93,102]. The popular methods are the sol-gel process, hydrothermal synthesis, precipitation in water solution, precipitation from microemulsions, vapour deposition and mechanochemical processes. ZnO NPs have been reported in different morphologies, like the nanoflake, nanoflower, nanobelt, nanorod and nanowire with different sizes. The mean particle size varied from few $\mathrm{nm}$ to $\mu \mathrm{m}$. The size and morphology of $\mathrm{ZnO}$ can be changed by tuning synthesis conditions and reactants [92]. Pholnak et al. tuned reaction time, temperature and mechanical 
forces during mixing the reactants to synthesize $\mathrm{ZnO}$. They found the $\mathrm{ZnO}$ morphology changed with different temperatures. The $\mathrm{ZnO}$ was hexagonal prisms and hexagonal linked rods at 70 and $80^{\circ} \mathrm{C}$, respectively. The morphology changed from hexagonal linked rods to sword-like rods when they applied ultrasonic wave during the mixing of the reactants. They also showed that the mean particle size can be changed due to the concentration of reagents. The mean particle size decreased from $1.2 \mu \mathrm{m}$ to $650 \mathrm{~nm}$, using a higher concentration of $\mathrm{C}_{6} \mathrm{H}_{12} \mathrm{~N}_{4}$ with $\mathrm{Zn}\left(\mathrm{NO}_{3}\right)_{2}$ [92]. In PU/ZnO composites' preparation, both pristine and functionalized $\mathrm{ZnO}$ were used. The pristine $\mathrm{ZnO}$ was mainly from commercially available sources. In functionalized $\mathrm{ZnO}$, the functionalization was done in different ways. It also depends on the attached functional group. However, the basic steps during functionalization were almost similar. Mostly the surface hydroxyl group of $\mathrm{ZnO}$ reacted with reactive group (mainly amine group or isocyanate group) to functionalize $\mathrm{ZnO}$.

\section{PU/ZnO Composite Dispersion Preparation}

The PU/ZnO composite dispersion preparation is summarized in Figure 2. Either an in situ polymerization (Process 1) or blending (Process 2) is adopted to prepare PU/ZnO composite dispersion, which is then followed by different techniques to form various application formats (see Table 1).

\subsection{In Situ Polymerization}

During in situ polymerization, steps such as prepolymer formation and chain extension are followed, similar to pristine PU dispersion preparation [19-27]. In situ polymerization is a popular synthesis process to prepare $\mathrm{PU} / \mathrm{ZnO}$ dispersion $[32,35,38,43,52,55,63,65-67,70,71,80,82,88]$, and it is almost similar to the preparation of pristine PU dispersion. During this type of polymerization, the polyol and diisocyanate monomers are charged together, to make an NCO-terminated prepolymer, which is followed by chain extension by using small-molecular-weight-based diol or amine. $\mathrm{ZnO}$ (pristine or functionalized) is mixed either monomer (polyol or isocyanate) or prepolymer (see Tables 2-4). Additional neutralization and water-dispersion steps are performed only for waterborne (WB) PU/ZnO dispersion [22-24]. In a typical procedure to prepare WBPU/ZnO [32,52], the PTMG, isophorone diisocyanate (IPDI) and 2,2-bis(hydroxymethyl) propionic acid (DMPA) in an NCO/OH molar ratio of 1.7 are mixed in a glass reactor, under a nitrogen atmosphere. The reaction continues until the NCO-terminated prepolymer is formed. $\mathrm{ZnO}$ is mixed with the prepolymer. Organic solvents such as acetone or 2-butanone are mixed with the reaction mixture to control the viscosity of the pre-polymer. Then, triethylamine (TEA) is added to neutralize the acid group of the prepolymer. The proper amount of water is added to the prepolymer that is dispersed in water. In the last step, all the free NCO groups of the prepolymer react to the amine group of ethylenediamine (EDA). This step mainly increases the molecular weight of the polymer. The organic solvent used is collected separately by a distillation process during the preparation of a WBPU dispersion [18]. If $\mathrm{ZnO}$ has any reactive groups (such as amine or hydroxyl) present, they react directly with isocyanate (see Scheme 1) [35]; otherwise, ZnO mainly interacts with PU by hydrogen bonding [32]. 
Table 1. Basic monomers, dispersion preparation methods and applications of $\mathrm{PU} / \mathrm{ZnO}$ composite.

\begin{tabular}{|c|c|c|c|c|}
\hline \multirow{2}{*}{ Application } & \multicolumn{2}{|l|}{ Composite Dispersion } & \multirow{2}{*}{ Preparation Process of Application } & \multirow{2}{*}{ Reference } \\
\hline & Basic Monomers & Preparation & & \\
\hline \multirow{11}{*}{ Coating } & Not mentioned, commercial grade & Blending & Solution casting & {$[31,34,36,37,51,91]$} \\
\hline & Not mentioned, commercial grade & Blending & Dip coating & {$[33,60,92]$} \\
\hline & Acrylic PU, commercial grade & Blending & Meyer rod & [76] \\
\hline & Not mentioned, commercial grade & Blending & Spray & {$[40,46,61,79]$} \\
\hline & Polyol, diisocyanate & In situ polymerization & Solution casting using square shaped applicator & [35] \\
\hline & Polyol, diisocyanate & In situ polymerization & Spin coating & [43] \\
\hline & Not mentioned, commercial grade & Blending & Spin coating & {$[54,77,85]$} \\
\hline & Not mentioned, commercial grade & Blending & Electro coating & {$[53,87]$} \\
\hline & Polyol, diisocyanate, pendant acid, 2-hydroxyethyl methacrylate & Blending & Automatic applicator & [78] \\
\hline & Not mentioned, commercial grade & Blending & Spiral applicator & [86] \\
\hline & Polyol, diisocyanate, pendant acid, triethylamine, ethylene diamine & Blending & Solution casting & [90] \\
\hline \multirow{2}{*}{ Membranes } & Not mentioned, commercial grade & Blending & Solution casting & {$[56,75]$} \\
\hline & Polyol, pendant acid, diisocyanate, butane diol (as a chain extender) & In situ polymerization & Precipitation process using warm distilled water & {$[65,66]$} \\
\hline \multirow{2}{*}{ Foam } & Polyol, diisocyanate & In situ polymerization & Water blown in an open mold & [38] \\
\hline & Polyol, diisocyanate, butane diol & Blending & Freeze-extraction & [68] \\
\hline Scaffold & Not mentioned, commercial grade & Blending & Electrospinning & [49] \\
\hline Hydrogel & Polyol, diisocyanate & In situ polymerization & Dipping & [67] \\
\hline \multirow{12}{*}{ Film } & Polyol, pendant acid, diisocyanate, tertiary amine (as a base), diamine (as a chain extender) & In situ polymerization & Solvent evaporation & {$[32,52,55,88]$} \\
\hline & Polyol, diisocyanate, butanediol & In situ polymerization & Solution casting using a ruler & [80] \\
\hline & $\begin{array}{l}\text { Polyol, pendant acid, diisocyanate, 2-hydroxyethyl acrylate, 2-hydroxyethyl methacrylate } \\
\text { pentaerythritol triacrylate, 2-hydroxypropyl acrylate, hydroxypropyl methacrylate, 4-methoxyphenol }\end{array}$ & In situ polymerization & Solvent evaporation & [71] \\
\hline & Polyol, disocyanate, methylene-bis-ortho-chloroaniline & In situ polymerization & Hot press & {$[63,70]$} \\
\hline & Disocyanate, $\mathrm{N}, \mathrm{N}-\mathrm{bis}(2$-hydroxyethyl)isonicotinamide & In situ polymerization & Heat treated at muffle furnace & [82] \\
\hline & Polyol, diisocyanate & Blending & Solution casting & {$[64,74]$} \\
\hline & Not mentioned, commercial grade & Blending & High volume low pressure (HVLP) & [69] \\
\hline & Not mentioned, commercial grade & Blending & Solution casting & {$[39,41,47,72,73]$} \\
\hline & Commercial grade, polyol diisocyanate, diamine & Solution blending & Solution casting & [50] \\
\hline & Polyester PU, commercial grade & Blending & Spin coating method, solution casting & [44] \\
\hline & Not mentioned, commercial grade & Melt processing & Compression moulding & [48] \\
\hline & Not mentioned, commercial grade & Solution blending & Drawdown & [59] \\
\hline Optical biosensor & Not mentioned, commercial grade & Spread over base PU & $\mathrm{ZnO}$ dried on polymerized $\mathrm{PU}$ & [45] \\
\hline Nanofiber & Not mentioned, commercial grade & Blending & Electrospinning & {$[57,89,93]$} \\
\hline Thermal pad & Polyol, disocyanate, furfuryl alcohol, bismaleimide & $\begin{array}{l}\mathrm{ZnO} / \text { stainless steel (SS) mesh and PU } \\
\text { prepared separately; PU solution poured } \\
\text { on } \mathrm{ZnO} / \text { stainless steel (SS) mesh }\end{array}$ & Solvent evaporation & [58] \\
\hline Flat Sheet & Not mentioned, commercial grade & PU sheet was immersed in $\mathrm{ZnO}$ solution & Dipping process & [62] \\
\hline
\end{tabular}


Table 2. Mixing of pristine $\mathrm{ZnO}$ during $\mathrm{PU} / \mathrm{ZnO}$ dispersion preparation.

\begin{tabular}{|c|c|c|c|c|c|c|}
\hline \multicolumn{2}{|c|}{ ZnO Premixed with Solvent } & \multicolumn{4}{|c|}{ Mixing Stage of $\mathrm{ZnO}$} & \multirow{3}{*}{ Reference } \\
\hline \multirow{2}{*}{ Yes } & \multirow{2}{*}{ No } & \multirow{2}{*}{$\begin{array}{c}\text { Mixed with Ready } \\
\text { PU }\end{array}$} & \multicolumn{3}{|c|}{ Mixed In Situ Polymerization } & \\
\hline & & & Polyol & Isocyanate & Prepolymer & \\
\hline$\ldots$ & $\sqrt{ }$ & $\sqrt{ }$ & $\ldots$ & $\ldots$ & $\ldots$ & {$[31,48,51,54,59-61,65,68,69,78,79,85,86,89,91-93]$} \\
\hline$\ldots$ & $\sqrt{ }$ & $\ldots$ & $\cdots$ & $\ldots$ & $\sqrt{ }$ & {$[32,52,82]$} \\
\hline$\sqrt{ }$ & $\ldots$ & $\ldots$ & $\ldots$ & $\ldots$ & $\sqrt{ }$ & {$[43,50]$} \\
\hline$\cdots$ & $\sqrt{ }$ & $\ldots$ & $\sqrt{ }$ & $\ldots$ & $\cdots$ & {$[38,63,70,80]$} \\
\hline$\sqrt{ }$ & $\ldots$ & $\sqrt{ }$ & $\ldots$ & $\ldots$ & $\ldots$ & {$[39,40,45-47,53,56,62,66,87]$} \\
\hline
\end{tabular}

Table 3. Mixing of pristine $\mathrm{ZnO}$ along with other nano particle/metal oxide/polymer during PU/ZnO dispersion preparation.

\begin{tabular}{|c|c|c|c|c|c|c|c|}
\hline \multirow{3}{*}{$\begin{array}{c}\text { Nano Particle/Metal } \\
\text { Oxide/Polymer }\end{array}$} & \multicolumn{2}{|c|}{$\begin{array}{c}\text { ZnO Premixed } \\
\text { with Solvent }\end{array}$} & \multicolumn{4}{|c|}{ Mixing Stage of $\mathrm{ZnO}$} & \multirow{3}{*}{ Ref. } \\
\hline & \multirow{2}{*}{ Yes } & \multirow{2}{*}{ No } & \multirow{2}{*}{$\begin{array}{l}\text { Mixed with } \\
\text { Ready PU }\end{array}$} & \multicolumn{3}{|c|}{ Mixed In Situ Polymerization } & \\
\hline & & & & Polyol & Isocyanate & Prepolymer & \\
\hline$f \mathrm{MWCNT}$ & $\sqrt{ }$ & $\ldots$ & $\sqrt{ }$ & $\ldots$ & $\ldots$ & $\ldots$ & [49] \\
\hline Graphene aerogel & $\ldots$ & $\sqrt{ }$ & $\ldots$ & $\sqrt{ }$ & $\ldots$ & $\ldots$ & [67] \\
\hline Cellulose-acetate & $\cdots$ & $\sqrt{ }$ & $\sqrt{ }$ & $\cdots$ & $\cdots$ & $\ldots$ & [75] \\
\hline Polylactide & $\ldots$ & $\sqrt{ }$ & $\sqrt{ }$ & $\ldots$ & $\ldots$ & $\ldots$ & [73] \\
\hline Chitosan & $\ldots$ & $\sqrt{ }$ & $\sqrt{ }$ & $\ldots$ & $\ldots$ & $\ldots$ & [64] \\
\hline stainless steel mesh & $\ldots$ & $\sqrt{ }$ & $\sqrt{ }$ & $\ldots$ & $\ldots$ & $\ldots$ & [58] \\
\hline $\mathrm{CdO}$ & $\sqrt{ }$ & $\ldots$ & $\sqrt{ }$ & $\ldots$ & $\ldots$ & $\ldots$ & [57] \\
\hline
\end{tabular}


Table 4. Mixing of functionalized $\mathrm{ZnO}$ during PU/ZnO dispersion preparation.

\begin{tabular}{|c|c|c|c|c|c|c|c|c|}
\hline \multirow{3}{*}{ Attached Functional Group in Modified ZnO } & \multirow{3}{*}{$\begin{array}{l}\text { Other Material } \\
\text { with } \mathrm{ZnO}\end{array}$} & \multicolumn{2}{|c|}{$\begin{array}{c}f \text {-ZnO Premixed } \\
\text { with Other Solvent }\end{array}$} & \multicolumn{4}{|c|}{ Mixing Stage of $\mathrm{ZnO}$} & \multirow{3}{*}{ Ref } \\
\hline & & \multirow{2}{*}{ Yes } & \multirow{2}{*}{ No } & \multirow{2}{*}{ Ready PU } & \multicolumn{3}{|c|}{ Mixed In Situ Polymerization } & \\
\hline & & & & & Polyol & Isocyanate & Prepolymer & \\
\hline 3-aminopropyltriethoxysilane & .. &.. & $\sqrt{ }$ & $\sqrt{ }$ & .. & .. & .. & [33] \\
\hline Poly(o-toluidine) & .. & $\sqrt{ }$ &. & $\sqrt{ }$ & .. & .. &. & [34] \\
\hline Amine & .. &.. & $\sqrt{ }$ & .. & $\sqrt{ }$ & .. & .. & [35] \\
\hline Lignin &.. & $\sqrt{ }$ & .. & $\sqrt{ }$ & .. & .. & .. & [36] \\
\hline Chitosan &.. & & $\sqrt{ }$ & $\sqrt{ }$ & .. &.. &.. & [37] \\
\hline $\begin{array}{l}\text { Aminopropyltriethoxysilane, } \\
\text { activated stearic acid and carbonyldiimidazole }\end{array}$ &. & $\sqrt{ }$ & .. & $\sqrt{ }$ &. &. & .. & [39] \\
\hline Magnesium & .. &.. & $\sqrt{ }$ & $\sqrt{ }$ & .. &.. &.. & [41] \\
\hline $\mathrm{CeO}_{2}$ &.. &.. & $\sqrt{ }$ & $\sqrt{ }$ &.. &.. &.. & [44] \\
\hline 2-aminoethyl-3-aminopropyltrimethoxysilane & .. &.. & $\sqrt{ }$ & $\sqrt{ }$ & .. & .. & .. & [54] \\
\hline 3-aminopropyltriethoxysilane & .. &.. & $\sqrt{ }$ & .. & .. & $\sqrt{ }$ &. & [55] \\
\hline Oleic acid & .. &.. & $\sqrt{ }$ & $\sqrt{ }$ & .. & .. & .. & [60] \\
\hline Hydroxy acrylate and toluene diisocyanate & .. &.. & $\sqrt{ }$ & .. &.. &.. & $\sqrt{ }$ & [71] \\
\hline Polyaniline & .. &.. & $\sqrt{ }$ & $\sqrt{ }$ & .. & .. & .. & [72] \\
\hline 3-(Trimethoxysilyl)propyl methacrylate &. &.. & $\sqrt{ }$ & .. & .. & .. & $\sqrt{ }$ & [74] \\
\hline 3-aminopropyltrimethoxysilane & $\begin{array}{l}\text { Corundum, } \\
\mathrm{SiO}_{2}\end{array}$ & .. & $\sqrt{ }$ & $\sqrt{ }$ & .. & .. & .. & [76] \\
\hline $\mathrm{Ag}$ & .. &.. & $\sqrt{ }$ & $\sqrt{ }$ & .. & .. & .. & [77] \\
\hline Amphiphilic PU &.. & $\sqrt{ }$ &.. & .. &.. & .. & $\sqrt{ }$ & [88] \\
\hline Polyaniline & Copper &.. & $\sqrt{ }$ & $\sqrt{ }$ & .. & .. & .. & [90] \\
\hline
\end{tabular}




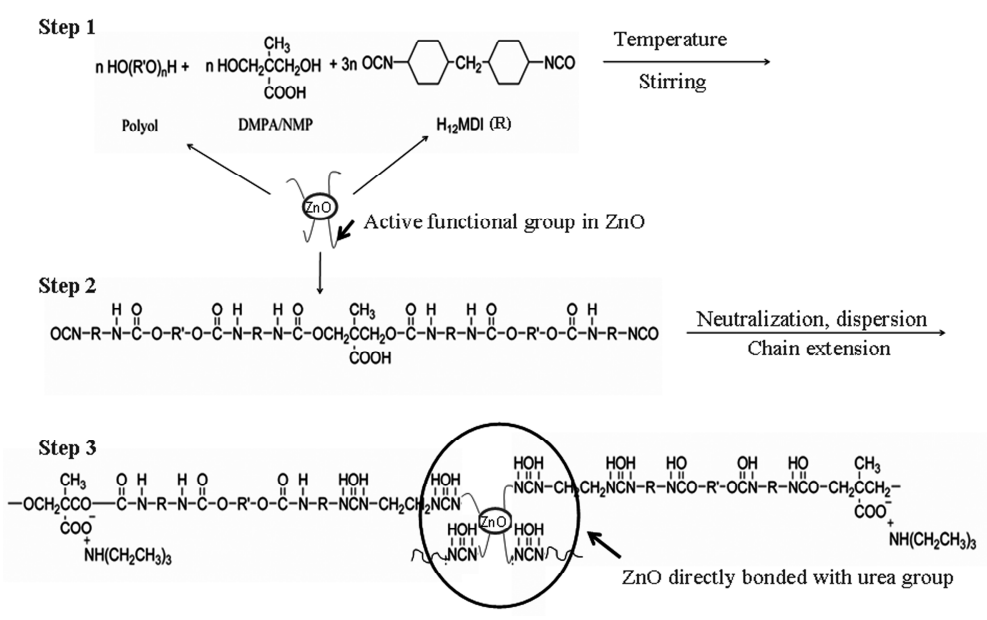

Scheme 1. Typical PU/ZnO composite dispersion preparation using functionalized $\mathrm{ZnO}$.

Completely different methods, such as (I) monomer mixing and bubble nucleation, (II) foam rising, (III) phase separation and cell opening, and (IV) foam formation, are used during the preparation of $\mathrm{PU} / \mathrm{ZnO}$ composite foam $[38,68]$.

\subsection{Blending}

Blending is a physical particle mixing process in polymer dispersion without any post-polymerization. Most of the reported [31,33,34,36,37,39-41,44,46,47,49-51,53,54,56,57,59-61,64, $68,69,72-79,85-87,89-93] \mathrm{PU} / \mathrm{ZnO}$ composite dispersions are prepared by following this process (see Tables 2-4). In this process, the prepared PU dispersion (synthesized or collected from commercial grade) is blended with different $\mathrm{ZnO}$ contents, to prepare the target $\mathrm{PU} / \mathrm{ZnO}$ composite (see Scheme 2). The defined $\mathrm{ZnO}$ content is mixed with ready PU dispersion, following the mechanical stirring or ultrasonicated technique mostly at room temperature. Most importantly, the mixing time with different $\mathrm{ZnO}$ content to achieve the homogeneous dispersion reported by different researchers varies $[31,34,35,40,60,69,79]$.

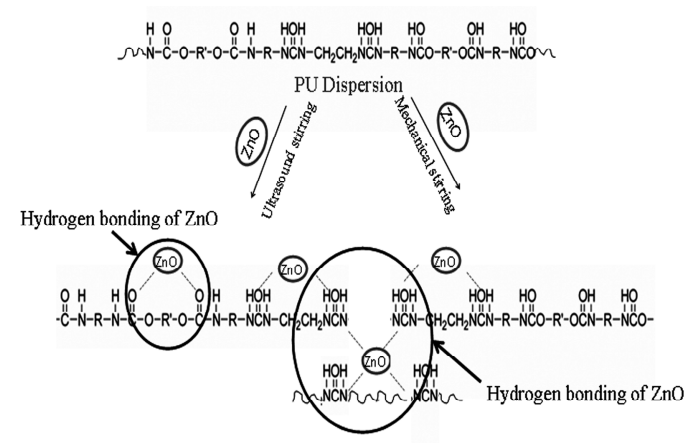

Scheme 2. Typical PU/ZnO composite dispersion preparation by blending process.

\subsection{PU/ZnO Composite Preparation for Different Application}

The prepared $\mathrm{PU} / \mathrm{ZnO}$ dispersion is used to make different composite film/coating/membrane for varieties application (see Table 1). The composite film/coating/membrane are formed by applying different methods, such as solution casting [31,34,36,37,51,91], dip coating [33,60,92], a Meyer rod method [76], spraying [40,46,61,79], spin coating [43,54,77,85], electrocoating [53,87], an automatic applicator method [78], a spiral applicator method [86], a freeze-extraction method [68], electrospinning [49], dipping [67], a solvent evaporation method [58], a hot press method [63,70], a high volume low pressure (HVLP) method [69], compression molding [48] and a drawdown method [59]. 
In most of the cases, the defined amount of dispersion poured into the substrate and kept an ambient condition to dry it completely. The dried coating further cured at moderate high temperature. The PU/ZnO composite properties highly depend on the mixed status of $\mathrm{ZnO}$. The composite properties are improved only by a homogeneous mixing of $\mathrm{ZnO}$. Otherwise, $\mathrm{ZnO}$ has detrimental effects on the composite properties. Most importantly, the optimum $\mathrm{ZnO}$ content to achieve target protective properties reported by different researchers varied, despite similar compositions and preparation processes [31,34,35,40,60,69,79].

\section{PU/ZnO Composite Dispersion Stability}

It is already proved that making a stable PU composite dispersion is challenging [23,25]. It depends on PU monomer, nanoparticle and mechanical forces [25]. The dispersion stability affected by both of nanoparticle-structure and -contents. The dispersion is stable up to certain nanoparticle contents. Polar-group-attached nanoparticle-based PU dispersion has higher stability [25]. The dispersion stability also varied with synthesis conditions. Although a lot of work has been done in PU/ZnO dispersion, only a few works mentioned their stability. In a stable composite dispersion, the particle remains in dispersion without any phase separation. The charges of particles make a repulsive force, which keeps the particles away from each other, to make the dispersion stable. In $\mathrm{PU} / \mathrm{ZnO}$, the dispersion was stable using both pristine and functionalized $\mathrm{ZnO}$. The functionalized $\mathrm{ZnO}$ can increase the dispersion stability [60]. G. Christopher functionalized $\mathrm{ZnO}$ with oleic acid, the functionalized $\mathrm{ZnO}$ based PU dispersion was more stable that the pristine $\mathrm{ZnO}$ [60]. The oleic acid directly bonded with $\mathrm{ZnO}$ to avoid the aggregation of particles due to repulsive forces of particles; eventually, the dispersion was stable. The homogeneous distribution of $\mathrm{ZnO}$ is also important for a longer shelf life. The dispersion with functionalized $\mathrm{ZnO}$ was stable for six months, whereas the pristine $\mathrm{ZnO}$ based dispersion was stable only for $10 \mathrm{~min}$.

\section{Key Factors of PU/ZnO Composite for Protecting Application}

The main application of $\mathrm{PU} / \mathrm{ZnO}$ composite was protective purposes, especially for corrosion [31,34,35,40,60,69,79], fouling [37,72], UV-degradation [31,33,36,39,40,44,54,74,76,85-88,92,93] and bacterial $[35,41,49,51,55,62,64-68,79,82,91,93]$. There are few common criteria of materials to use as a protective material. The adhesion and self-healing properties are very important for any protective material. Moreover, the particle size of a nano particle also has a huge impact on polymer-composite properties.

\subsection{Adhesion}

Adhesion is an important parameter for any material used for coating on any substrate. Adhesion can be defined as the attachment of a material to a surface; usually, such a material is called an adhesive. Although there are natural adhesives, widely used adhesives are mainly synthetic polymer-based materials. Widely used polymer-based adhesives include rubber, polyacrylate, epoxy and polyurethane [1-3]. Usually, adhesion is quantified by strength, called adhesive strength. To evaluate the adhesive strength, it is necessary to detach the tested coating from the underlying metal substrate. In most cases, the adhesive strength is measured by a pull-off test. The general mechanism of improvement of adhesive strength is the increase in intermolecular forces between the substrate (mainly metal) and the adhesive. Recently, PU adhesive materials have been widely used due to not only their good adhesive strength but also their formulation flexibility and excellent weather resistance. The other advantage of PU adhesive materials is their flexible nature to bond many different substrates, such as fabrics, wood, rubber, plastics, leather and metals, making these adhesives applicable in the packing, transport, buildings and furniture industries. The preparation of PU adhesive material is also simple, consisting mainly of a reaction between polyol and diisocyanate. Most recent landmark advances in PU adhesives are environmentally friendly, solventless, biodegradable and renewable; all of these advances in PU make possible a broad range of applications. The adhesive strength of PU adhesives 
was improved by using appropriate monomers, crosslinkers and fillers [21-27]. Different nanoparticles and metal oxides have also been used as fillers to improve the adhesive strength of coatings. Among the different less-toxic metal oxides, $\mathrm{ZnO}$ was used in the PU coating. An improved adhesive strength was mostly recorded by using $\mathrm{ZnO}$ in the $\mathrm{PU} / \mathrm{ZnO}$ coating. The $\mathrm{ZnO}$ content, adhesive strength and adhesion mechanism are summarized in Table 5 . Steel substrates were mainly used to check the adhesive of $\mathrm{PU} / \mathrm{ZnO}$ coatings. Both unmodified and modified $\mathrm{ZnO}$ were used, although the $\mathrm{ZnO}$ content varied widely from 0.1 to $6.0 \mathrm{wt} . \%$. The adhesive strength also varied, and the adhesive strength increased with increasing $\mathrm{ZnO}$ content. The mentioned reasons for the adhesive strength are the chemical interaction between PU and the $\mathrm{ZnO}$ surface, reduced UV-degradation, hydrogen bonds and coordination bonds, and the $\mathrm{ZnO}$ reinforcement effect. The surface hydroxyl group of $\mathrm{ZnO}$ interacted with urethane, urea and ether groups (electronegative element), making a strong bond, and hence the adhesive strength increased. At exposed condition, the coating usually degraded by UV radiation. The degraded coating started to chain scission, which also help to passing electrolyte through the coating. Ultimately it shows negative effect on adhesive strength. As $\mathrm{ZnO}$ protect the UV-degradation, it also assumed that the chain scission is also opposed. Thus, $\mathrm{ZnO}$ protects the adhesive strength at exposed condition. Researchers have studied the effect of $\mathrm{ZnO}$ on the adhesive strength of $\mathrm{PU} / \mathrm{ZnO}$ coatings during $\mathrm{PU} / \mathrm{ZnO}$ composite coating for different practical applications, such as corrosion [40,52,79], antibacterial and antistatic properties [79,91], UV-degradation [87], anti-electrostatic properties [70], photopolymerization [71] and weather resistance [78]. Only Bravo et al. showed the effect of temperature on adhesive strength during $\mathrm{PU} / \mathrm{ZnO}$ composite preparation. A higher adhesive strength was recorded by using a PU/ZnO composite prepared at a high temperature [40]. Other reviewed articles only examined the adhesive strength with different $\mathrm{ZnO}$ contents; in all cases, the adhesive strength increased with increasing $\mathrm{ZnO}$ content.

Table 5. Adhesion of PU/ZnO composite materials.

\begin{tabular}{|c|c|c|c|c|c|c|c|c|}
\hline \multicolumn{3}{|c|}{$\mathrm{ZnO}$} & \multirow[b]{2}{*}{ Failure Type } & \multirow[b]{2}{*}{$\begin{array}{l}\text { Testing } \\
\text { Method }\end{array}$} & \multirow[b]{2}{*}{ Thickness } & \multirow[b]{2}{*}{ Substrate } & \multirow[b]{2}{*}{ Mechanism } & \multirow[b]{2}{*}{ Ref. } \\
\hline Nature & Used Content & $\begin{array}{c}\text { Adhesive } \\
\text { Strength } \\
\text { (MPa) }\end{array}$ & & & & & & \\
\hline Pristine & $\begin{array}{l}2.0 \mathrm{wt} . \% \\
6.0 \mathrm{wt} . \%\end{array}$ & $\begin{array}{l}3.8 \\
4.7\end{array}$ & $\begin{array}{l}\text { Not } \\
\text { mentioned }\end{array}$ & Pull-off test & $20 \mu \mathrm{m}$ & $\begin{array}{l}\text { AISI } 1018 \\
\text { carbon steel } \\
\text { (CS) }\end{array}$ & $\begin{array}{l}\text { (1) Chemical } \\
\text { interaction between } \\
\text { PU and } \mathrm{ZnO} \\
\text { surface.(2) Reduced } \\
\text { UV-degradation }\end{array}$ & [40] \\
\hline Pristine & $\begin{array}{c}0 \\
0.25 \text { wt. } \% \\
0.50 \text { wt. } \% \\
0.75 \text { wt. } \% \\
1.00 \text { wt. } \%\end{array}$ & $\begin{array}{c}7.1 \\
8.4 \\
11.4 \\
12.2 \\
15.4\end{array}$ & $\begin{array}{c}\text { Not } \\
\text { mentioned }\end{array}$ & Pull-off test & $\begin{array}{c}\text { Not } \\
\text { mentioned }\end{array}$ & Carbon steel & $\begin{array}{l}\text { (1) Hydrogen bond } \\
\text { which increased with } \\
\text { increasing } \mathrm{ZnO} \\
\text { content.( } 2 \text { ) } \\
\text { Coordination bond } \\
\text { between metal ions } \\
\text { and free CO groups }\end{array}$ & [52] \\
\hline $\begin{array}{l}\text { Hydroxy acrylate } \\
\text { and toluene } \\
\text { diisocyanate } \\
\text { functionalized }\end{array}$ & $\begin{array}{c}0.2 \text { wt. } \% \\
0.4 \text { wt. } \% \\
0.6 \text { wt. } \% \\
0.8 \text { wt. } \% \\
1.00 \text { wt. } \% \\
\end{array}$ & $\begin{array}{l}1 \\
1 \\
0 \\
0 \\
0\end{array}$ & $\begin{array}{c}\text { Not } \\
\text { mentioned }\end{array}$ & $\begin{array}{c}\mathrm{GB} / \mathrm{T} \\
1720-1979\end{array}$ & $\begin{array}{c}\text { Not } \\
\text { mentioned }\end{array}$ & $\begin{array}{c}\text { Not } \\
\text { mentioned }\end{array}$ & Not explained & [71] \\
\hline Pristine & $\begin{array}{c}0 \% \\
1.0 \text { wt. } \% \\
3.0 \text { wt. } \% \\
5.0 \text { wt. } \%\end{array}$ & $\begin{array}{l}4.5 \\
7.1 \\
7.6 \\
8.0 \\
\end{array}$ & $\begin{array}{c}\text { Not } \\
\text { mentioned }\end{array}$ & Pull-off test & $\begin{array}{c}\text { Not } \\
\text { mentioned }\end{array}$ & Glass plate & Not explained & [78] \\
\hline Pristine & $\begin{array}{c}0 \% \\
0.1 \text { wt. } \% \\
0.5 \text { wt. } \% \\
1.0 \text { wt. } \% \\
1.5 \text { wt. } \% \\
2.0 \text { wt. } \% \\
\end{array}$ & $\begin{array}{l}4 \\
4 \\
6 \\
7 \\
8 \\
8\end{array}$ & $\begin{array}{l}\text { Not } \\
\text { mentioned }\end{array}$ & Pull-off test & $\begin{array}{c}\text { Not } \\
\text { mentioned }\end{array}$ & Steel & $\begin{array}{l}\mathrm{ZnO} \text { reinforcement } \\
\text { effect }\end{array}$ & [79] \\
\hline $\begin{array}{l}\text { Polyaniline } \\
\text { functionalized }\end{array}$ & $\begin{array}{c}\text { WBPU } \\
\text { WBPU-PANI (5.0 } \\
\text { wt. } \%) \\
\text { WBPU-Cu-ZnO } \\
(5.0 \text { wt. } \%) \\
\text { WBPU-P-Cu-ZnO } \\
\text { (5.0 wt. } \%)\end{array}$ & $\begin{array}{l}7.10 \\
7.20 \\
7.40 \\
7.70\end{array}$ & $\begin{array}{c}100 \% \\
\text { Adhesion } \\
25 \% \text { Cohesion } \\
40 \% \text { Cohesion } \\
80 \% \text { Cohesion }\end{array}$ & Pull-off test & $\begin{array}{c}\text { Not } \\
\text { mentioned }\end{array}$ & steel & $\begin{array}{l}\text { Polar and hydrophilic } \\
\text { nature improve the } \\
\text { adhesive strength }\end{array}$ & [90] \\
\hline
\end{tabular}




\subsection{Self-Healing}

Recent trends of polymer have been for it to regain its properties, especially the protective properties; this helps increase the shelf life of the material. Polymer with self-healing properties can be used for this purpose [99-105]. Such materials are getting much attention recently in the polymer and coating industry. This property is being utilized in many engineering materials. The main advantage of this property is automatic repairing after damage. In most of the cases, this damage cannot be seen with the naked eye, but this property helps to repair without external activity. The coating acts as a sustainable material. Usually polymers' extrinsic and intrinsic properties are responsible for their self-healing properties. In the extrinsic case, the healing agent is pre-embedded intentionally during the coating preparation. In intrinsic coating, the coating possesses a repairing capacity through its internal chemical bond. Though both techniques are applicable for polymers, the intrinsic healing has more of an advantage, as this technique allows multiple time repairing [103-105]. Moreover, this technique allows good compatibility of bulk polymers, in which the interactions of functional groups triggered by heat, light and $\mathrm{pH}$. Most importantly, the polymer chain has temporarily fast mobility to heal the damage [99]. In PU, the repairing mainly done by hydrogen bonds of multifunctional groups, such as urethane, urea, allophanate, etc. It has also been mentioned recently that reversible multi-crosslinks in PU can make multifunctional healing [58,99]. PU/ZnO coating also showed a self-healing property $[58,100,101]$. The inclusion of $\mathrm{ZnO}$ increases the hydrogen bond, as well as the shape memory, of the composite; hence, the self-healing property also increases $[100,101]$. The hydrogen bond can make a supramolecular structure, centered of $\mathrm{ZnO}$. This structure helps to heal the scratched area [103-105].

\subsection{ZnO Particle Size}

The mean particle size of nanomaterial is important, especially for protective purposes of PU composite coatings. The protective properties, such as corrosion, UV-degradation and hydrophobicity, all are hugely affected by the different particle sizes of the same nanoparticles in a similar formulation. Based on the reviewed articles, the range of $\mathrm{ZnO}$ mean particle size was varied from 20 to $650 \mathrm{~nm}$ in $\mathrm{PU} / \mathrm{ZnO}$ composite. Therefore, the used $\mathrm{ZnO}$ can be classified as macro- and nanoparticle. However, the mean particle size was below $100 \mathrm{~nm}$ mostly. Only few articles compared the effect of mean particle size of $\mathrm{ZnO}$ on their properties. Yang et al. [97] used $\mathrm{ZnO}$ to evaluate the effect of particle size of $\mathrm{ZnO}$ on a coating's protective properties. The used mean particle size was 20 and $400 \mathrm{~nm}$. The coating corrosion protection increased from using both $\mathrm{ZnO}$ particle sizes. It was also found that the coating corrosion protection rate was much higher from using the smaller size than the larger one. When the mean particle size is small, the particle has greater surface to absorb more polymers; hence, the corrosion resistance increased [97,98]. Moreover the smaller particle size can easily penetrate the coating's micro-holes and, thus, oppose more strongly to pass the electrolyte. Ultimately, the corrosion resistance was further improved [97].

\section{PU/ZnO Composite Applications}

$\mathrm{PU} / \mathrm{ZnO}$ composite has a wide range of application. $\mathrm{ZnO}$ itself has various protective properties. Additionally, $\mathrm{ZnO}$ functionalization with certain groups broadens $\mathrm{PU} / \mathrm{ZnO}$ composite applications in different areas. Recent advances toward green and renewable resources of PU have also contributed to attracting industries, which has promoted an accelerated growth of new applications for $\mathrm{PU} / \mathrm{ZnO}$ composite.

\subsection{Antibacterial/Antimicrobial Application}

Bacterial attack on different polymer material is a common issue. In a suitable environment, bacteria can grow on the material, thus making it a huge challenge to use that material. To protect the material from bacterial attack, different approaches have been followed. One of the useful 
ways is to enhance antibacterial properties by using different metal oxides nanoparticles with the proper material [84]. $\mathrm{ZnO}$ has also been used in $\mathrm{PU} / \mathrm{ZnO}$ nanocomposites to enhance antibacterial properties [84]. It is common knowledge that a pristine PU material has negligible antibacterial properties [35,84]; however, with the inclusion of $\mathrm{ZnO}$ in the $\mathrm{PU}$, the antibacterial properties improve significantly. Different PU/ZnO composites, such as coatings [35], foams [68], membranes [65,66], packaging films [64] and scaffolds [49], have been used for antibacterial purposes. The antibacterial properties of the PU/ZnO composite are summarized in Table 6.

Although there are many reports $[35,41,49,51,55,83]$ available on the antibacterial mechanism of $\mathrm{ZnO}$, it is very difficult to find the exact antibacterial mechanism of the PU/ZnO composite. Notably, the antibacterial mechanism of the PU/ZnO composite has not yet been clearly evidenced. However, factors contributing to the antibacterial mechanism have been mentioned by different researchers (see Scheme 3) and are listed as follows:

1. The release of antimicrobial $\mathrm{Zn}^{2+}$ ion $[55,64,79,82]$;

2. The antimicrobial property was due to $\mathrm{ZnO}[35,41,48,51,65,66,68]$;

3. It is the electrostatic interaction between the nanoparticles and microorganisms that ultimately kills the bacteria [49]; and

4. Reactive oxygen species are formed, which are also toxic to microorganisms $[41,49,51,55,62,64,79]$.

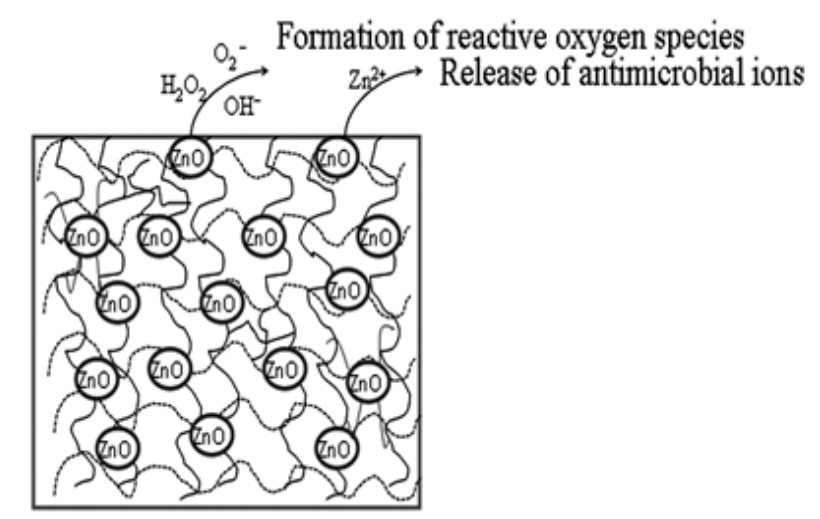

Scheme 3. Mechanism of $\mathrm{PU} / \mathrm{ZnO}$ antibacterial coating.

Besides the microporous structure of the composite [82], the mechanical damage of the cell membrane by $\mathrm{ZnO}$ penetration also helps to enhance the antibacterial activity $[55,79]$. At least one of the mentioned factors should be available when using the $\mathrm{PU} / \mathrm{ZnO}$ composite for an antibacterial purpose. 
Table 6. Antibacterial properties of PU/ZnO composite.

\begin{tabular}{|c|c|c|c|c|c|c|c|c|c|c|}
\hline \multirow{2}{*}{$\mathrm{PU} / \mathrm{ZnO}$ Composite } & \multirow{2}{*}{$\begin{array}{l}\text { Attached Functional Group } \\
\text { with ZnO }\end{array}$} & \multirow{2}{*}{ Antibacterial Test } & \multirow{2}{*}{ ZnO Content } & \multicolumn{6}{|c|}{ Antibacterial Activity } & \multirow{2}{*}{ Ref. } \\
\hline & & & & E. coli & K. pneumonia & S. ureus & B. subtilis & A. niger & A. brasiliensis & \\
\hline Hybrid composite coatings & 3-aminopropyltrimethoxysilane & Luria-Bertani agar medium & $\begin{array}{l}1.0 \text { wt. } \% 1.5 \text { wt. } \% \\
2.0 \text { wt. } \%\end{array}$ & $\begin{array}{c}+ \\
++ \\
++\end{array}$ & $\begin{array}{c}++ \\
+ \\
+\end{array}$ & $\begin{array}{c}+ \\
+ \\
++ \\
++\end{array}$ & $\begin{array}{l}- \\
- \\
-\end{array}$ & $\begin{array}{l}\text { N.D } \\
\text { N.D } \\
+++\end{array}$ & $\begin{array}{l}\cdots \\
\cdots \\
\cdots\end{array}$ & [35] \\
\hline Composite film & Magnesium-doped & MacConkey agar & $\begin{array}{c}1.0 \text { wt. } \% 2.5 \text { wt. } \% \\
5.0 \text { wt. } \%\end{array}$ & $\begin{array}{c}67.6 \% \\
73.5 \% \\
93.3 \% \\
\text { (Antibacterial rate) } \\
\end{array}$ & $\begin{array}{l}\cdots \\
\cdots \\
\cdots\end{array}$ & $\begin{array}{l}\cdots \\
\cdots \\
\cdots \\
\end{array}$ & $\begin{array}{l}\cdots \\
\cdots \\
\cdots\end{array}$ & $\begin{array}{l}\cdots \\
\cdots \\
\cdots\end{array}$ & $\begin{array}{l}\cdots \\
\cdots \\
\cdots\end{array}$ & [41] \\
\hline Hybrid Scaffold & MWCNT & Tryptic soy broth medium & $0.2 \quad 0.4$ wt. $\%$ & 148\% (Inhibition zone) & $\cdots$ & $\begin{array}{l}158 \% \text { (Inhibition } \\
\text { zone) }\end{array}$ & $\cdots$ & $\cdots$ & $\cdots$ & [49] \\
\hline Coating & $\cdots$ & Agar dilution method & $\begin{array}{l}1.0 \\
2.0 \\
3.0 \\
4.0 \\
\end{array}$ & $\begin{array}{l}20 \\
26 \\
71 \\
90\end{array}$ & $\begin{array}{l} \\
\cdots \\
\cdots \\
\cdots\end{array}$ & $\begin{array}{l}\ldots \\
\ldots \\
\ldots \\
\ldots\end{array}$ & $\begin{array}{l}0 \\
18 \\
61 \\
84 \\
\end{array}$ & $\begin{array}{l}\ldots \\
\ldots \\
\ldots \\
\ldots\end{array}$ & $\begin{array}{l}\ldots \\
\ldots \\
\ldots \\
\ldots\end{array}$ & [51] \\
\hline composite & 3-aminopropyltriethoxysilane & Agar plate & $\begin{array}{l}0.5 \mathrm{wt.} \% \\
1.0 \mathrm{wt} . \% \\
1.5 \mathrm{wt} . \% \\
2.0 \mathrm{wt} . \% \\
4.0 \mathrm{wt} . \% \\
\end{array}$ & $\begin{array}{c}42 \\
12 \\
7 \\
3 \\
0 \\
\text { (survival ratio\%) }\end{array}$ & $\begin{array}{l}\ldots \\
\cdots \\
\cdots \\
\cdots \\
\cdots \\
\end{array}$ & $\begin{array}{c}70 \\
42 \\
25 \\
8 \\
0 \\
\text { (survival ratio\%) }\end{array}$ & $\begin{array}{l} \\
\ldots \\
\ldots \\
\ldots \\
\ldots \\
\cdots\end{array}$ & $\begin{array}{l} \\
\ldots \\
\ldots \\
\ldots \\
\ldots \\
\cdots \\
\end{array}$ & $\begin{array}{l} \\
\ldots \\
\ldots \\
\ldots \\
\ldots \\
\ldots\end{array}$ & [55] \\
\hline Bactericidal coating sheet & Crystal violet & $\begin{array}{c}\text { MacConkey agar } \\
\text { Mannitol Salt agar }\end{array}$ & Not mentioned & +++ & $\cdots$ & +++ & $\cdots$ & $\cdots$ & $\cdots$ & [62] \\
\hline Packaging film & Chitosan & Agar plate & $\begin{array}{l}1.0 \% \\
3.0 \% \\
5.0 \% \\
\end{array}$ & $\begin{array}{c}+ \\
++ \\
++ \\
+++\end{array}$ & $\begin{array}{l}\ldots \\
\cdots \\
\cdots\end{array}$ & $\begin{array}{c}+ \\
+ \\
++ \\
+++\end{array}$ & $\begin{array}{l} \\
\cdots \\
\cdots \\
\cdots\end{array}$ & $\begin{array}{l} \\
\cdots \\
\cdots \\
\cdots\end{array}$ & $\begin{array}{l} \\
\cdots \\
\cdots \\
\end{array}$ & [64] \\
\hline Membranes & $\cdots$ & Sabouraud agar & $\begin{array}{l}5.0 \mathrm{wt} . \% \\
10.0 \mathrm{wt} . \% \\
\end{array}$ & $\cdots$ & $\cdots$ & $\cdots$ & $\cdots$ & $\cdots$ & $\begin{array}{c}+ \\
+ \\
++\end{array}$ & [65] \\
\hline Membranes & $\cdots$ & $\begin{array}{c}\text { Minimum inhibitory } \\
\text { concentration method (cell } \\
\text { viability) }\end{array}$ & $\begin{array}{l}2.0 \text { wt.\% } \\
4.0 \text { wt.\% } \\
6.0 \text { wt.\% } \\
8.0 \text { wt. } \% \\
\end{array}$ & 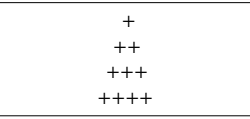 & $\begin{array}{l}\ldots \\
\cdots \\
\ldots \\
\cdots \\
\end{array}$ & $\begin{array}{l}\ldots \\
\cdots \\
\ldots \\
\ldots \\
\end{array}$ & $\begin{array}{l}\ldots \\
\cdots \\
\ldots \\
\ldots\end{array}$ & $\begin{array}{l}\ldots \\
\cdots \\
\ldots \\
\ldots \\
\end{array}$ & $\begin{array}{l}\ldots \\
\ldots \\
\ldots \\
\ldots\end{array}$ & [66] \\
\hline Composite foam & $\cdots$ & Mueller Hinton Agar & 10.0 wt.\% & $\begin{array}{c}11^{3} \mathrm{CFU} \text { (colony } \\
\text { forming unit) reduction }\end{array}$ & $\ldots$ & $\begin{array}{l}10^{3} \mathrm{CFU} \\
\text { reduction }\end{array}$ & $\cdots$ & $\cdots$ & $\cdots$ & [68] \\
\hline Coating & $\cdots$ & Well diffusion & $\begin{array}{l}0.1 \mathrm{wt.} \% \\
0.5 \mathrm{wt.} \% \\
1.0 \mathrm{wt.} \% \\
1.5 \mathrm{wt.} \% \\
2.0 \mathrm{wt.} \%\end{array}$ & $\begin{array}{c}15 \% \\
40 \% \\
65 \% \\
80 \% \\
10 \% \% \\
\text { (Inhibition) } \\
\end{array}$ & $\begin{array}{l}\cdots \\
\cdots \\
\cdots \\
\cdots \\
\cdots \\
\end{array}$ & $\begin{array}{l}\cdots \\
\ldots \\
\cdots \\
\cdots \\
\cdots \\
\end{array}$ & $\begin{array}{c}20 \% \\
50 \% \\
75 \% \\
90 \% \\
100 \% \\
\text { (Inhibition) } \\
\end{array}$ & $\begin{array}{l}\cdots \\
\cdots \\
\cdots \\
\cdots \\
\cdots \\
\end{array}$ & $\begin{array}{l}\cdots \\
\cdots \\
\cdots \\
\cdots \\
\cdots \\
\end{array}$ & [79] \\
\hline Hybrid materials & $\ldots$ & Agar plate & Not mentioned & $\sqrt{ }+++$ & $\ldots$ & $\ldots$ & $\ldots$ & $\ldots$ & $\ldots$ & [82] \\
\hline Varnished coating & $\cdots$ & Counted number of colonies & $\begin{array}{l}0.4 \text { wt. } \% \\
0.7 \text { wt. } \%\end{array}$ & 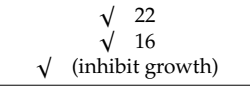 & $\begin{array}{l}\ldots \\
\ldots\end{array}$ & $\begin{array}{c}8(85 \%) \\
2(95 \%) \\
\text { (inhibit growth) } \\
\end{array}$ & $\cdots$ & $\cdots$ & $\begin{array}{l}\cdots \\
\cdots\end{array}$ & [91] \\
\hline Nano fiber & $\cdots$ & & $\begin{array}{l}1.0 \\
5.0\end{array}$ & $\begin{array}{l}\checkmark \ldots \\
\sqrt{ } \ldots\end{array}$ & $\begin{array}{l}60.0 \\
98.7 \\
\end{array}$ & $\begin{array}{l}99.9 \\
99.9 \\
\end{array}$ & $\begin{array}{l}\ldots \\
\cdots \\
\cdots\end{array}$ & $\begin{array}{l}\ldots \\
\ldots \\
\end{array}$ & $\begin{array}{l}\ldots \\
\cdots \\
\end{array}$ & [93] \\
\hline
\end{tabular}

" +" = it has antibacterial activity, " -" = it has no antibacterial activity, N.D. = it has not determined. 


\subsection{Anticorrosion Application}

Corrosion is a natural phenomenon; most bare metals corrode quickly. Corrosion occurs as a result of electron transfer in a suitable corrosive environment. A metal was used as the anode to generate ions to initiate the corrosion process. Different methods involve inhibition of dopant anions, cathodic or anodic protection, barrier protection and shifting of electrochemical interfaces to protect the metal from corrosive environments $[34,40,60]$. To prolong the anticorrosion properties of metals, different organic coatings have been used on metals and their structures. PU is also used as an inhibitor, as well as a coating material. Different hydrophobic functional groups, such as siloxane and fluoro groups, have been attached to PU to improve its anticorrosion properties. To further improve the anticorrosion properties, different metal oxides as a nanoparticle have also been used in PU coatings. $\mathrm{ZnO}$ nanoparticle has also been considered to enhance the anticorrosion properties of $\mathrm{PU}$. The corrosion protection mechanism and $\mathrm{ZnO}$ criteria of $\mathrm{PU} / \mathrm{ZnO}$ nanocomposite coatings are summarized in Table 7 . Commercially available PU is mainly used for this purpose. Different $\mathrm{ZnO}$ contents, from low to high content, are considered. Interestingly, the optimum $\mathrm{ZnO}$ content varies. As the commercial supplier did not disclose the monomers or their ratio, it is difficult to determine the reason for the differences in optimum $\mathrm{ZnO}$ content.

Table 7. Corrosion properties of $\mathrm{PU} / \mathrm{ZnO}$ composite.

\begin{tabular}{|c|c|c|c|c|c|c|c|}
\hline \multicolumn{3}{|c|}{$\mathrm{ZnO}$} & \multirow[b]{2}{*}{ PU Monomer } & \multirow{2}{*}{$\begin{array}{c}\mathrm{E}_{\text {corr }}(\mathrm{mV}) \\
\text { (at Optimum } \\
\text { Content) }\end{array}$} & \multirow[b]{2}{*}{ Substrate } & \multirow[b]{2}{*}{ Protection Mechanism } & \multirow[b]{2}{*}{ Ref. } \\
\hline Nature & $\begin{array}{c}\text { Used } \\
\text { Content }\end{array}$ & $\begin{array}{c}\text { Optimum } \\
\text { Content }\end{array}$ & & & & & \\
\hline Pristine & $\begin{array}{l}0.1 \text { wt. } \%, \\
1.0 \text { wt. } \%\end{array}$ & 0.1 wt. $\%$ & $\begin{array}{l}\text { Not mentioned, } \\
\text { commercial grade }\end{array}$ & $\cdots$ & Mild steel & $\begin{array}{l}\text { (1) Improved barrier resistance } \\
\text { and (2) reduced UV-degradation }\end{array}$ & [31] \\
\hline $\begin{array}{l}\text { Poly(o-toluidine) } \\
\text { functionalized }\end{array}$ & $\begin{array}{l}7.0 \text { wt. } \%, \\
14.0 \text { wt. } \%\end{array}$ & 7.0 wt. $\%$ & $\begin{array}{l}\text { Not mentioned, } \\
\text { commercial grade }\end{array}$ & -669.5 & Carbon steel & $\begin{array}{l}\text { (1) Passive layer formation, (2) } \\
\text { synergistic effects of } \\
\text { poly(o-Toluidine) and (3) coating } \\
\text { porosity reduced by addition } \\
\text { of } \mathrm{ZnO}\end{array}$ & [34] \\
\hline $\begin{array}{c}\text { Amine } \\
\text { functionalized }\end{array}$ & $\begin{array}{l}1.0 \text { wt. } \%, \\
2.0 \text { wt. } \%\end{array}$ & $2.0 \mathrm{wt} . \%$ & Polyol, diisocyanate & $\cdots$ & Mild steel & $\begin{array}{l}\text { (1) Crosslinked structures } \\
\text { formation, which ultimately } \\
\text { improved barrier resistance }\end{array}$ & [35] \\
\hline Pristine & $\begin{array}{l}2.0 \text { wt. } \% \text {, } \\
4.0 \text { wt. } \%, \\
6.0 \text { wt. } \%\end{array}$ & 6.0 wt. $\%$ & $\begin{array}{l}\text { Not mentioned, } \\
\text { commercial grade }\end{array}$ & -692 & $\begin{array}{l}\text { AISI } 1018 \\
\text { carbon steel }\end{array}$ & $\begin{array}{l}\text { (1) Improved hydrophobicity and } \\
\text { (2) compactness of the coatings }\end{array}$ & [40] \\
\hline $\begin{array}{c}\text { Oleic acid } \\
\text { functionalized }\end{array}$ & $\begin{array}{l}0.1 \text { wt. } \%, \\
0.3 \text { wt. } \%\end{array}$ & 0.3 wt. $\%$ & $\begin{array}{l}\text { Not mentioned, } \\
\text { commercial grade }\end{array}$ & -678 & Mild steel & $\begin{array}{l}\text { (1) Filler acted to seal coatings } \\
\text { pores and (2) improve the barrier } \\
\text { protection }\end{array}$ & [60] \\
\hline Pristine & $\begin{array}{l}1.0 \text { wt. } \%, \\
3.0 \text { wt. } \%, \\
5.0 \text { wt. } \%\end{array}$ & $\begin{array}{l}1.0 \mathrm{wt.} \%, \\
3.0 \mathrm{wt} . \%\end{array}$ & $\begin{array}{l}\text { Not mentioned, } \\
\text { commercial grade }\end{array}$ & $\cdots$ & $\begin{array}{l}\text { Low carbon } \\
\text { steel }\end{array}$ & $\begin{array}{l}\text { (1) Chemical interaction between } \\
\mathrm{ZnO} \text { and polyurethane }\end{array}$ & [69] \\
\hline Pristine & $\begin{array}{l}0.1 \text { wt. } \%, \\
2.0 \text { wt. } \%\end{array}$ & $2.0 \mathrm{wt} . \%$ & $\begin{array}{l}\text { Not mentioned, } \\
\text { commercial grade }\end{array}$ & $\cdots$ & Steel & (1) Improve barrier resistance & [79] \\
\hline
\end{tabular}

The overall protection mechanism is summarized in Scheme 4. The anticorrosion enhancement can be ascribed to improved UV-degradation [31], barrier resistance by making compact and crosslinked structures [35], synergistic effects between the attached functional groups on $\mathrm{ZnO}$ [34], increased hydrophobicity [40], sealers [60] and chemical interactions [69].

Pristine $\mathrm{ZnO}$ has been used in $\mathrm{PU} / \mathrm{ZnO}$ composite coatings by few researchers to protect the metal surface from corrosion [31,40,69,79]. It was reported that $\mathrm{ZnO}$ can act as an electrolyte barrier [31,79], UV absorber [31] and hydrophobic compound [40]. Functionalized $\mathrm{ZnO}$ also improved the corrosion resistance of the $\mathrm{PU} / \mathrm{ZnO}$ composite coating $[34,35,60]$. 


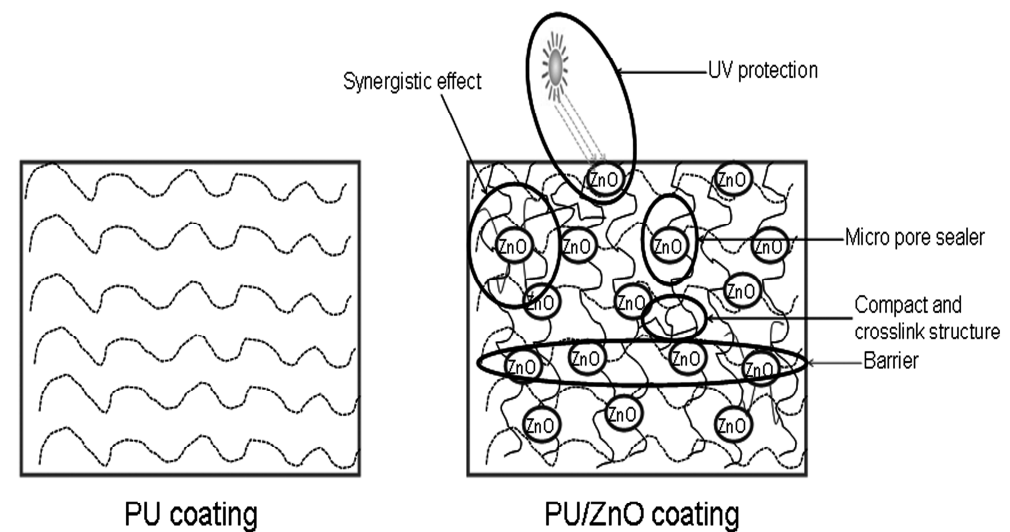

Scheme 4. Mechanism of PU/ZnO anticorrosion coating.

\subsection{Anti-UV-Degradation Application}

Degradation over time is common to all kinds of polymer matrices. It is a partial decomposition of the matrix, and ultimately, it makes fragments with high molecular weight. Different factors that initiate degradation can be chemical (such as aggressive media and oxygen) as well as physical (such as heat, radiation and stress). The matrix degradation rate depends on the chemical structure, impurities (such as remaining catalyst and monomer), the exposed environment and the use of stabilizers. In an open-air atmosphere, most of the exposed PU material (mainly coating and film) is rapidly degraded by UV absorption. There are many different ways to enhance the anti-UV-degradation process. Metal oxide as nanoparticle use is one of the familiar methods to improve the anti-UV-degradation of the PU coating. $\mathrm{ZnO}$ has also been considered by many researchers $[31,33,36,39,40,44,54,74,76,85-88,92,93]$. A summary of their work is given in Table 8. They used different forms and contents of $\mathrm{ZnO}$. The mechanism of anti-UV-degradation of the $\mathrm{PU} / \mathrm{ZnO}$ compositeis improving its $\mathrm{UV}$ absorbing nature and the presence of synergistic effects.

\subsection{Gas Separation Application}

Polymeric membranes have been used in gas separation for almost 30 years. Although there are some other methods, such as pressure swing adsorption, amine scrubbing and cryogenic distillation, in gas separation applications, the main advantage of using polymeric membranes is their easy application, comparatively low cost and low energy consumption. Especially in the refinery industry, gas separation is crucial due to $\mathrm{H}_{2}$ purification, $\mathrm{CO}_{2}$ capture and hydrocarbon separation. There are published reports on using either $\mathrm{PU}$ or $\mathrm{ZnO}$ in membranes for gas separation, but only one article has been published using $\mathrm{PU} / \mathrm{ZnO}$ composite membranes [56]. The authors showed that the permeability of $\mathrm{N}_{2}, \mathrm{CO}_{2}$ and $\mathrm{CH}_{4}$ depends on the $\mathrm{ZnO}$ content. The permeability increased with increasing $\mathrm{ZnO}$ content up to $0.50 \mathrm{wt} . \%$, while the permeability decreased by using $\mathrm{ZnO}$ above $0.50 \mathrm{wt} . \%$. Up to 0.50 $\mathrm{wt} . \%$, the $\mathrm{ZnO}$ was placed properly in the membrane, without creating barrier. Thus, the permeability increased. Above $0.50 \mathrm{wt} . \%$, the excess amount of $\mathrm{ZnO}$ made a barrier, and ultimately the permeability decreased [56].

\subsection{Medical/Biomaterial Application}

PU material use in medical applications is common. A few researchers have also used PU/ZnOcomposite materials for this purpose $[49,65,68,73]$. The mechanical strength, biocompatibility and antibacterial properties of PU/ZnOcomposite materials are the main advantages for their use in medical applications. The main uses of PU/ZnOcomposite materials for medical and biomedical applications are hospital bedding, tubing, wound dressing, surgical drapes, injection equipment and implants. 
Table 8. Anti-UV-degradation properties of $\mathrm{PU} / \mathrm{ZnO}$ composites.

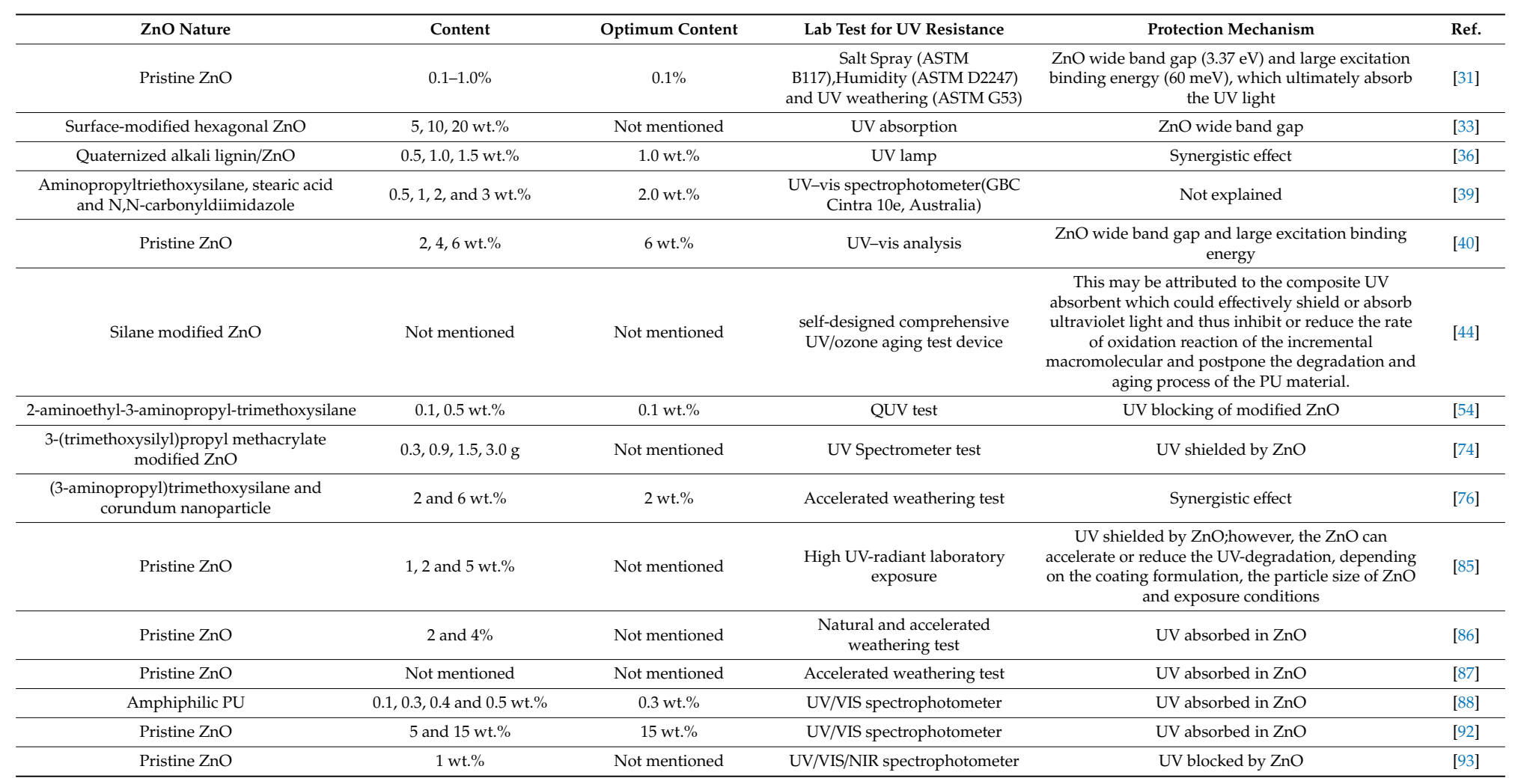




\subsection{Antistatic Application}

Recently, the antistatic properties of materials and coatings are in demand because this property plays an important role in protecting a surface from static electricity. Generally, antistatic coatings are made by using metal oxides or nanoparticles. The $\mathrm{PU} / \mathrm{ZnO}$ composite coating also exhibits good antistatic properties when $\mathrm{ZnO}$ is mixed homogeneously. The antistatic properties are also enhanced by using aniline groups during the preparation of the $\mathrm{PU} / \mathrm{ZnO}$ composite coating $[70,90]$.

\subsection{Marine Antifouling Application}

Marine applications have opened a new field for PU/ZnOcomposite materials [37]. Due to the banning of toxic tin-based compounds, new initiatives are in high demand in the marine paint and coating industry. A few published articles already prove that PU can be an option as an antifouling coating if the monomer and its contents are maintained properly. PU/ZnOcomposite coatings have also been used to protect the surface from the attachment of the fouler. Using a proper amount of $\mathrm{ZnO}$ in the PU/ZnOcomposite coating provides excellent fouling protection [37,72].

\subsection{Electronic Device Application}

The band gap $(\mathrm{Eg}=3.3 \mathrm{eV})$ and exciton binding energy $(60 \mathrm{meV})$ of $\mathrm{ZnO}$ make it very attractive in electronic device applications, especially for memory arrays, microlasers, biosensors and chemical sensing. Only one work has been published using $\mathrm{PU} / \mathrm{ZnO}$ composite material in this regard, and the $\mathrm{PU} / \mathrm{ZnO}$ composite coating showed dielectric properties [43].

\section{Future Prospects}

All the reports reviewed here did not find any difficulties or challenges during the preparation of the various $\mathrm{PU} / \mathrm{ZnO}$ composites. However, the use of large differences in $\mathrm{ZnO}$ content is quite confusing. In most cases, they do not mention the stability and shelf life of the solution after preparation. Only one article [60] mentioned the stability of $\mathrm{PU} / \mathrm{ZnO}$ dispersion. The authors mentioned a very short storing time (only $10 \mathrm{~min}$ ), using pristine $\mathrm{ZnO}$. However, the storing time increased to six months by using functionalized $\mathrm{ZnO}$. Counting $10 \mathrm{~min}$ storing is practically unacceptable to consider for a commercial and practical application. Surely, the other factors such as $\mathrm{ZnO}$ particle size, as well as PU monomer and their contents, may contribute to improve this limitation.

In addition, most of the applications are proved in the lab. Thus, they did not consider the real environment or simulated conditions. The lack of data in real environments may raise questions about the suitability of $\mathrm{PU} / \mathrm{ZnO}$ composites in a real environment.

The availability of monomers and easy synthesis processes help to make a variety of $\mathrm{PU} / \mathrm{ZnO}$ composites, which broadens their applications. Recent initiatives to use renewably resourced monomers of PU also open a new window of PU/ZnO composite materials due to environmental legislation. Another advantage of $\mathrm{ZnO}$ is its functionalization, which can alter the $\mathrm{PU} / \mathrm{ZnO}$ chemistry to find new areas of application.

The majority of the PU/ZnO composites are used for anticorrosion, anti-UV-degradation and antibacterial coating purposes. In all cases, it is necessary to check the adhesive strength. Due to inadequate adhesive strength, the coating might not be useful for a long time. Unfortunately, only a few researchers have evaluated the adhesive strength of coatings. None of them considered any harsh conditions during their adhesive test. It is also important to consider harsh application conditions, which will help determine the real practical application value of the material. At the same time, a self-healing property was mostly not considered. It is an area that should be more focused, in order to overcome many coating failures.

Though large amounts of works are found on PU/ZnO composite material, there are a few areas that have not been considered both in synthesis and application. Only in situ polymerization and blending are considered during the preparation of $\mathrm{PU} / \mathrm{ZnO}$ composite material. Not a single report was 
found based on controlled radical polymerization (CRP), such as RAFT or ATRP, and post-dispersion polymerization. These synthesis processes have been applied in pristine $\mathrm{PU}$ and have improved the matrix properties. By the CRP method, certain functional groups (e.g., azide groups) can be attached to the parent polymer chain, and the azide groups have various applications, due to their anticorrosion and antibacterial properties, which ultimately can broaden the application of PU/ZnO composite materials. In addition, the molecular weight can be controlled with the ATRP method; the ability to control molecular weight has a huge impact on certain properties. Post-polymerization can create a crosslinked structure, as well as provide the addition of certain functional groups in the parent chain, which may improve hydrophobicity. A large effort has also been noted for the synthesis of a PU matrix without the use of toxic diisocyanate. Unfortunately, no report has been found to synthesize PU/ZnO composite without isocyanate. If scientists are able to realize a $\mathrm{PU} / \mathrm{ZnO}$ composite without isocyanate, the number of potential applications will dramatically increase.

Only two articles mention the use of CNTs and Ag nanoparticles in a PU/ZnO composite. Furthermore, there are many other nanomaterials available other than CNTs and Ag. By considering other nanoparticles (such as clay, Au nanoparticles and functionalized graphene), a new PU/ZnO composite material may be synthesized. These matrices can be used in anticorrosion, antifouling and anti-UV-degradation processes.

In the last decade, biodegradable matrices have become a prime interest. Unfortunately, most PU/ZnO composite studies overlook biodegradability. Only one report [64] was found on a biodegradable $\mathrm{PU} / \mathrm{ZnO}$ composite material. More biodegradable PU/ZnO composite materials need to be explored, as biodegradable materials are now in high demand for human safety and environmental sustainability.

No report was found on the application of $\mathrm{PU} / \mathrm{ZnO}$ composite material in implants. As PU/ZnO composite material has already been proven to be a good antibacterial and anticorrosive material, a PU/ZnO composite material may be used in implant applications.

$\mathrm{PU}$ is a very good biomaterial. Many studies have been performed on PU biomaterials. A PU/ZnO composite material may also be used as a healing material due to its antibacterial properties.

There are many reports available on lithium batteries using both PU and ZnO. However, not a single report was found using $\mathrm{PU} / \mathrm{ZnO}$ composite materials in lithium battery applications.

For gas separation applications, only one article has been published using a $\mathrm{PU} / \mathrm{ZnO}$ composite membrane. PU membranes are widely used for gas separation, and a very recent idea is the use of MOFs in gas separation applications. Therefore, MOFs with $\mathrm{PU} / \mathrm{ZnO}$ composite membranes may be a very promising $\mathrm{CO}_{2}$ reduction application.

The PU/ZnO composite can be prepared in a more environmentally friendly way if scientists consider renewably resourced monomers and water as the main solvent. By considering the many different properties of the $\mathrm{PU} / \mathrm{ZnO}$ composite, an increase in new applications can be explored in the near future.

Funding: This research received no external funding.

Acknowledgments: The author would like to acknowledge the support provided by the Deanship of Scientific Research (DSR), at King Fahd University of Petroleum and Minerals (KFUPM), for funding this work through project No. SB191018. I also acknowledged to Eyasin Arafat, Department of Mechanical Engineering, King Fahd University of Petroleum and Minerals, to help to completed the manuscript.

Conflicts of Interest: There is no potential conflict of interest.

\section{References}

1. Chattopadhyay, D.; Webster, D.C. Thermal stability and flame retardancy of polyurethanes. Prog. Polym. Sci. 2009, 34, 1068-1133. [CrossRef]

2. Chattopadhyay, D.; Raju, K. Structural engineering of polyurethane coatings for high performance applications. Prog. Polym. Sci. 2007, 32, 352-418. [CrossRef] 
3. Rahman, M.M.; Rabbani, M.M.; Saha, J.K. Polyurethane and Its Derivatives. In Functional Polymers; Jafar Mazumder, M.A., Sheardown, H., Al-Ahmed, A., Eds.; Springer International Publishing: Cham, Switzerland, 2019; pp. 1-16. ISBN 9783319920672.

4. Madbouly, S.A.; Otaigbe, J.U. Recent advances in synthesis, characterization and rheological properties of polyurethanes and POSS/polyurethane nanocomposites dispersions and films. Prog. Polym. Sci. 2009, 34, 1283-1332. [CrossRef]

5. Xie, F.; Zhang, T.; Bryant, P.; Kurusingal, V.; Colwell, J.M.; Laycock, B. Degradation and stabilization of polyurethane elastomers. Prog. Polym. Sci. 2019, 90, 211-268. [CrossRef]

6. Alinejad, M.; Henry, C.; Nikafshar, S.; Gondaliya, A.; Bagheri, S.; Chen, N.; Singh, S.K.; Hodge, D.B.; Nejad, M. Lignin-based polyurethanes: Opportunities for bio-based foams, elastomers, coatings and adhesives. Polymers 2019, 11, 1202. [CrossRef] [PubMed]

7. Burke, A.; Hasirci, N. Polyurethanes in Biomedical Applications. In Biomaterials. Advances in Experimental Medicine and Biology; Hasirci, N., Hasirci, V., Eds.; Springer: Boston, MA, USA, 2004; pp. 83-101.

8. Howard, G.T. Biodegradation of polyurethane: A review. Int. Biodeterior. Biodegrad. 2002, 49, $245-252$. [CrossRef]

9. Ismail, E.A.; Motawie, A.; Sadek, E. Synthesis and characterization of polyurethane coatings based on soybean oil-polyester polyols. Egypt. J. Pet. 2011, 20, 1-8. [CrossRef]

10. Park, Y.G.; Lee, Y.H.; Rahman, M.M.; Park, C.C.; Kim, H.D. Synthesis and properties of waterborne fluorinated polyurethane-acrylate using a solvent-/emulsifier-free method. Coll. Polym. Sci. 2015, 293, 1369-1382. [CrossRef]

11. Gurunathan, T.; Mohanty, S.; Nayak, S.K. Effect of reactive organoclay on physicochemical properties of vegetable oil-based waterborne polyurethane nanocomposites. RSC Adv. 2015, 5, 11524-11533. [CrossRef]

12. Alagi, P.; Choi, Y.J.; Hong, S.C. Preparation of vegetable oil-based polyols with controlled hydroxyl functionalities for thermoplastic polyurethane. Eur. Polym. J. 2016, 78, 46-60. [CrossRef]

13. Alagi, P.; Hong, S.C. Vegetable oil-based polyols for sustainable polyurethanes. Macromol. Res. 2015, 23, 1079-1086. [CrossRef]

14. Fridrihsone-Girone, A.; Stirna, U.; Misāne, M.; Lazdina, B.; Deme, L. Spray-applied 100\% volatile organic compounds free two component polyurethane coatings based on rapeseed oil polyols. Prog. Org. Coat. 2016, 94, 90-97. [CrossRef]

15. Ionescu, M.; Radojčić, D.; Wan, X.; Shrestha, M.L.; Petrović, Z.S.; Upshaw, T.A. Highly functional polyols from castor oil for rigid polyurethanes. Eur. Polym. J. 2016, 88, 736-749. [CrossRef]

16. Charlon, M.; Heinrich, B.; Matter, Y.; Couzigné, E.; Donnio, B.; Avérous, L. Synthesis, structure and properties of fully biobased thermoplastic polyurethanes, obtained from a diisocyanate based on modified dimer fatty acids, and different renewable diols. Eur. Polym. J. 2014, 61, 197-205. [CrossRef]

17. Veronese, V.B.; Menger, R.K.; Forte, M.M.C.; Petzhold, C.L. Rigid polyurethane foam based on modified vegetable oil. J. Appl. Polym. Sci. 2011, 120, 530-537. [CrossRef]

18. Rahman, M.M.; Zahir, M.H.; Kim, H.D. Synthesis and properties of waterborne polyurethane(WBPU)/modified lignin amine (MLA) adhesive: A promising adhesive material. Polymers 2016, 8, 318. [CrossRef] [PubMed]

19. Zia, K.M.; Bhatti, H.N.; Bhatti, I.A. Methods for polyurethane and polyurethane composites, recycling and recovery: A review. React. Funct. Polym. 2007, 67, 675-692. [CrossRef]

20. Pauzi, N.N.P.N.; Majid, R.A.; Dzulkifli, M.H.; Yahya, M.Y. Development of rigid bio-based polyurethane foam reinforced with nanoclay. Compos. Part B Eng. 2014, 67, 521-526. [CrossRef]

21. Rahman, M.M.; Kim, J.H.; Kim, H.D. Characterization of waterborne polyurethane/clay nanocomposite adhesives containing different amounts of ionic groups. J. Adhes. Sci. Technol. 2007, 21, 1575-1588. [CrossRef]

22. Kumar, A.M.; Rahman, M.M.; Gasem, Z.M. A promising nanocomposite from CNTs and nano-ceria: Nanostructured fillers in polyurethane coatings for surface protection. RSC Adv. 2015, 5, 63537-63544. [CrossRef]

23. Rahman, M.M.; Kim, E.Y.; Lim, K.; Lee, W.K. Morphology and properties of waterborne polyurethane/CNT nanocomposite adhesives with various carboxyl acid salt groups. J. Adhes. Sci. Technol. 2009, 23, 839-850. [CrossRef] 
24. Rahman, M.M.; Suleiman, R.; Kim, H.D. Effect of functionalized multiwalled carbon nanotubes on weather degradation and corrosion of waterborne polyurethane coatings. Korean J. Chem. Eng. 2017, 34, 2480-2487. [CrossRef]

25. Rahman, M.M. Stability and properties of waterborne polyurethane/clay nanocomposite dispersions. J. Coat. Technol. Res. 2017, 14, 1357-1388. [CrossRef]

26. Rahman, M.M. A Promising Coating of Nanostructured Graphene-Ceria Nanofillers in Polyurethane for Corrosion Protection. In CORROSION 2017; NACE International: New Orleans, LA, USA, 2017.

27. Rahman, M.M.; Kim, H.D.; Lee, W.K. Properties of waterborne polyurethane adhesives: Effect of chain extender and polyol content. J. Adhes. Sci. Technol. 2009, 23, 177-193. [CrossRef]

28. Porta, M.; Nguyen, M.T.; Yonezawa, T.; Tokunaga, T.; Ishida, Y.; Tsukamoto, H.; Shishino, Y.; Hatakeyama, Y. Titanium oxide nanoparticle dispersions in a liquid monomer and solid polymer resins prepared by sputtering. New J. Chem. 2016, 40, 9337-9343. [CrossRef]

29. Ghorbani, H.R.; Alizadeh, V.; Mehr, F.P.; Jafarpourgolroudbary, H.; Erfan, K.; Yeganeh, S.S. Preparation of polyurethane/CuO coating film and the study of antifungal activity. Prog. Org. Coat. 2018, 123, 322-325. [CrossRef]

30. Alam, M.; Alandis, N.M.; Zafar, F.; Sharmin, E.; Al-Mohammadi, Y.M. Polyurethane-TiO 2 nanocomposite coatings from sunflower-oil-based amide diol as soft segment. J. Macromol. Sci. Part A 2018, 55, 698-708. [CrossRef]

31. Dhoke, S.K.; Rajgopalan, N.; Khanna, A.S. Effect of Nano-Zinc oxide particles on the performance behavior of waterborne polyurethane composite coatings. Int. J. Mater. Sci. 2012, 2, 47-55.

32. Soares, R.R.; Carone, C.; Einloft, S.; Ligabue, R.; Monteiro, W.F. Synthesis and characterization of waterborne polyurethane/ZnO composites. Polym. Bull. 2014, 71, 829-838. [CrossRef]

33. Pholnak, C.; Sirisathitkul, C.; Soontaranon, S.; Rugmai, S. UV-Vis absorption and small angle X-ray scattering spectra of commercial polyurethane coating filled with zinc oxide. Natl. Acad. Sci. Lett. 2016, 39, 125-128. [CrossRef]

34. Zhang, J.; Li, Y.; Hu, C.; Huang, W.; Su, L. Anti-corrosive properties of waterborne polyurethane/poly(o-toluidine)-ZnO coatings in $\mathrm{NaCl}$ solution. J. Adhes. Sci. Technol. 2019, 33, 1047-1065. [CrossRef]

35. Siyanbola, T.O.; Sasidhar, K.; Rao, B.V.S.K.; Narayan, R.; Olaofe, O.; Akintayo, E.T.; Raju, K.V.S.N. Development of functional polyurethane-ZnO hybrid nanocomposite coatings from Thevetia peruviana seed oil. J. Am. Oil Chem. Soc. 2015, 92, 267-275. [CrossRef]

36. Wang, H.; Qiu, X.; Liu, W.; Fu, F.; Yang, D. A novel lignin/ZnO hybrid nanocomposite with excellent UV absorption ability and its application in transparent polyurethane coating. Ind. Eng. Chem. Res. 2017, 56, 11133-11141. [CrossRef]

37. Abiraman, T.; Kavitha, G.; Rengasamy, R.; Balasubramanian, S. Antifouling behavior of chitosan adorned zinc oxide nanorods. RSC Adv. 2016, 6, 69206-69217. [CrossRef]

38. Mogy, S.A.; Youssef, R.S.; Megeed, A.A.A. Processing of polyurethane nanocomposite reinforced with nanosized zinc oxide: Effect on mechanical and acoustic properties. Egypt. J. Chem. 2019, 62, 333-341.

39. Chen, H.; Yang, D.; Guo, Z. Dispersivity of modified ZnO and characterization of polyurethane/ZnO composites. Polym. Compos. 2014, 35, 237-244. [CrossRef]

40. Bravo, P.S.; Lopez, D.D.A.; Huerta, A.M.T.; Crespo, M.A.D.; Ramirez, D.P.; Sibaja, S.B.B.; Alvarez, A.C.F. Investigation of $\mathrm{ZnO} /$ waterborne polyurethane hybrid coatings for corrosion protection of AISI 1018 carbon steel substrates. Metall. Mater. Trans. A 2019, 50, 4799-4813.

41. Kasi, G.; Viswanathan, K.; Sedeghi, K.; Seo, J. Optical, thermal and structural properties of polyurethane in Mg-doped zinc oxide nanoparticles for antibacterial activity. Prog. Org. Coat. 2019, 133, 309-315. [CrossRef]

42. Ferrone, E.; Araneo, R.; Notargiacomo, A.; Pea, M.; Rinaldi, A. ZnO nanostructures and electrospun $\mathrm{ZnO}$-polymeric hybrid nanomaterials in Biomedical, health and sustainability applications. Nanomaterials 2019, 9, 1449. [CrossRef]

43. Velayutham, T.S.; Majid, W.H.A.; Gan, W.C.; Zak, A.K.; Gan, S.N. Theoretical and experimental approach on dielectric properties of $\mathrm{ZnO}$ nanoparticles and polyurethane/ZnO nanocomposites. J. Appl. Phys. 2012, 112, 054106. [CrossRef] 
44. Wang, H.; Wang, Y.; Liu, D.; Sun, Z.; Wang, H. Effects of additives on weather-resistance properties of polyurethane films exposed to ultraviolet radiation and ozone atmosphere. J. Nanomater. 2014, 2014, 487343. [CrossRef]

45. Preety, N.; Hooda, V. A novel polyurethane/nano ZnO matrix for immobilization of chitinolytic enzymes and optical sensing of chitin. Int. J. Biol. Macromol. 2018, 106, 1173-1183. [CrossRef] [PubMed]

46. Song, H.J.; Zhang, Z.Z.; Men, X.H.; Luo, Z.Z. A study of the tribological behavior of nano-ZnO-filled polyurethane composite coatings. Wear 2010, 269, 79-85. [CrossRef]

47. Awad, S.; Chen, H.; Chen, G.; Gu, X.; Lee, J.L.; Hady, E.E.A.; Jean, Y.C. Free Volumes, Glass Transitions, and Cross-Links in Zinc Oxide/Waterborne Polyurethane Nanocomposites. Macromolecules 2011, 44, $29-38$. [CrossRef]

48. Cabal, B.; Sevillano, D.; García, E.F.; Alou, L.; Suárez, M.; González, N.; Moya, J.S.; Torrecillas, R. Bactericidal $\mathrm{ZnO}$ glass-filled thermoplastic polyurethane and polydimethyl siloxane composites to inhibit biofilm-associated infections. Sci. Rep. 2019, 9, 1-11. [CrossRef] [PubMed]

49. Shrestha, B.K.; Shrestha, S.; Tiwari, A.P.; Kim, J.I.; Ko, S.W.; Kim, H.J.; Park, C.H.; Kim, C.S. Bio-inspired hybrid scaffold of zinc oxide-functionalized multi-wall carbon nanotubes reinforced polyurethane nanofibers for bone tissue engineering. Mater. Des. 2017, 133, 69-81. [CrossRef]

50. Zheng, J.; Ozisik, R.; Siegel, R.W. Disruption of self-assembly and altered mechanical behavior in polyurethane/zinc oxide nanocomposites. Polymer 2005, 46, 10873-10882. [CrossRef]

51. Li, J.H.; Honga, R.Y.; Li, M.Y.; Li, H.Z.; Zheng, Y.; Ding, J. Effects of ZnO nanoparticles on the mechanical and antibacterial properties of polyurethane coatings. Prog. Org. Coat. 2009, 64, 504-509. [CrossRef]

52. Mishra, A.K.; Mishra, R.S.; Narayan, R.; Raju, K.V.S.N. Effect of nano ZnO on the phase mixing of polyurethane hybrid dispersions. Prog. Org. Coat. 2010, 67, 405-413. [CrossRef]

53. Rashvand, M.; Ranjbar, Z. Effect of nano-ZnO particles on the corrosion resistance of polyurethane-based waterborne coatings immersed in sodium chloride solution via EIS technique. Prog. Org. Coat. 2013, 76, 1413-1417. [CrossRef]

54. Hang, T.T.X.; Dung, N.T.; Truc, T.A.; Duong, N.T.; Truoc, B.V.; Vu, P.G.; Hoang, T.; Thanh, D.T.M.; Olivier, M.G. Effect of silane modified nano $\mathrm{ZnO}$ on UV degradation of polyurethane coatings. Prog. Org. Coat. 2015, 79, 68-74. [CrossRef]

55. Ma, X.Y.; Zhang, W.D. Effects of flower-like ZnO nanowhiskers on the mechanical, thermal and antibacterial properties of waterborne polyurethane. Polym. Degrad. Stab. 2009, 94, 1103-1109. [CrossRef]

56. Soltani, B.; Asghari, M. Effects of ZnO nanoparticle on the gas separation performance of polyurethane mixed matrix membrane. Membranes 2017, 7, 43. [CrossRef] [PubMed]

57. Yousef, A.; Barakat, N.A.M.; Deyab, S.S.A.; Nirmala, R.; Pant, B.; Kim, H.Y. Encapsulation of CdO/ZnO NPs in PU electrospun nanofibers as novel strategy for effective immobilization of the photocatalysts. Colloids Surf. A 2012, 401, 8-16. [CrossRef]

58. Ji, C.; Li, J.; Wang, Y.; Yan, C.; Zhang, G.; Sun, R.; Wong, C.P. Enhanced thermal conductivity of networked stainless steel/ZnO/PU composite for thermal pad application. Mater. Res. Express 2019, 6, 076526. [CrossRef]

59. Awad, S.; Rashdi, A.A.; Hady, E.E.A.; Jean, Y.C.; Horn, J.D.V. Free volume properties of the zinc oxide nanoparticles/waterborne polyurethane coating system studied by a slow positron beam. J. Compos. Mater. 2019, 53, 1765-1775. [CrossRef]

60. Christopher, G.; Kulandainathan, M.A.; Harichandran, G. Highly dispersive waterborne polyurethane/ZnO nanocomposites for corrosion protection. J. Coat. Technol. Res. 2015, 12, 657-667. [CrossRef]

61. Salla, J.; Pandey, K.K.; Srinivas, K. Improvement of UV resistance of wood surfaces by using ZnO nanoparticles. Polym. Degrad. Stab. 2012, 97, 592-596. [CrossRef]

62. Sehmi, S.K.; Noimark, S.; Bear, J.C.; Peveler, W.J.; Bovis, M.; Allan, E.; MacRobert, A.J.; Parkin, I.P. Lethal photosensitisation of Staphylococcus aureus and Escherichia coli using crystal violet and zinc oxide-encapsulated polyurethane. J. Mater. Chem. B 2015, 3, 6490-6500. [CrossRef]

63. Guo, C.; Zheng, Z.; Zhu, Q.; Wang, X. Preparation and characterization of polyurethane/ZnO nanoparticle composites. Polym. Plast. Technol. Eng. 2007, 46, 1161-1166. [CrossRef]

64. Saral, S.K.; Indumathi, M.P.; Rajarajeswari, G.R. Mahua oil-based polyurethane/chitosan/nano ZnO composite films for biodegradable food packaging applications. Int. J. Biol. Macromol. 2019, 124, 163-174. 
65. Vlad, S.; Tanase, C.; Macocinschi, D.; Ciobanu, C.; Balaes, T.; Filip, D.; Gostin, I.N.; Gradinaru, L.M. Antifungal behavior of polyurethane membranes with zinc oxide nanoparticles. Dig. J. Nanomater. Biostruct. 2012, 7, $51-58$.

66. Vlad, S.; Gradinaru, L.M.; Ciobanu, C.; Macocinschi, D.; Filip, D.; Spiridon, I.; Gradinaru, R.V. Polycarbonate urethane-hydroxypropyl cellulose membranes with zinc oxide nanoparticles. Cellul. Chem. Technol. 2015, 49, 905-913.

67. Zhou, Y.; Wang, X.; Liu, X.; Sheng, D.; Ji, F.; Dong, L.; Xu, S.; Wu, H.; Yang, Y. Multifunctional $\mathrm{ZnO}$ /polyurethane-based solid-solid phase change materials with graphene aerogel. Sol. Energy Mater. Sol. Cells 2019, 193, 13-21. [CrossRef]

68. Bužarovska, A.; Dinescu, S.; Lazar, A.D.; Serban, M.; Pircalabioru, G.G.; Costache, M.; Gualandi, C.; Avérous, L. Nanocomposite foams based on flexible biobased thermoplastic polyurethane and $\mathrm{ZnO}$ nanoparticles as potential wound dressing materials. Mater. Sci. Eng. C 2019, 104, 109893. [CrossRef]

69. Virgawati, E.; Soegijono, B. Thermal behaviour and corrosion resistance of nano-ZnO/polyurethane film. J. Phys. Conf. Ser. 2018, 985, 012032. [CrossRef]

70. Guo, C.; Zhu, Q.; Zheng, Z.; Wang, X. Tetrapod-shaped ZnO whiskers reinforced polyurethane. J. Polym. Eng. 2007, 27, 357-369. [CrossRef]

71. Feng, J.; Ye, D. Polymerizable ZnO photoinitiators of surface modification with hydroxyl acrylates and photopolymerization with UV-curable waterborne polyurethane acrylates. Eur. Polym. J. 2019, 120, 109252. [CrossRef]

72. Mooss, V.A.; Hamza, F.; Zinjarde, S.S.; Athawale, A.A. Polyurethane films modified with polyaniline-zinc oxide nanocomposites for biofouling mitigation. Chem. Eng. J. 2019, 359, 1400-1410. [CrossRef]

73. Marycz, K.; Maredziak, M.; Grzesiak, J.; Szarek, D.; Lis, A.; Laska, J. Polyurethane/polylactide-blend films doped with zinc ions for the growth and expansion of human olfactory ensheathing cells (OECs) and adipose-derived mesenchymal stromal stem cells (ASCs) for regenerative medicine applications. Polymers 2016, 8, 175. [CrossRef]

74. Kim, D.; Jeon, K.; Lee, Y.; Seo, J.; Seo, K.; Han, H.; Khan, S.B. Preparation and characterization of UV-cured polyurethane acrylate/ZnO nanocomposite films based on surface modified ZnO. Prog. Org. Coat. 2012, 74, 435-442. [CrossRef]

75. Rajeswari, A.; Vismaiya, S.; Pius, A. Preparation, characterization of nano ZnO-blended cellulose acetate-polyurethane membrane for photocatalytic degradation of dyes from water. Chem. Eng. J. 2017, 313, 928-937. [CrossRef]

76. Haniffa, M.A.C.M.; Ching, Y.C.; Chuah, C.H.; Ching, K.Y.; Liou, N.S. Synergistic effect of (3-Aminopropyl)Trimethoxysilane treated $\mathrm{ZnO}$ and corundum nanoparticles under UV-irradiation on UV-cutoff and IR-absorption spectra of acrylic polyurethane based nanocomposite coating. Polym. Degrad. Stab. 2019, 159, 205-216. [CrossRef]

77. Ye, X.; Wang, Z.; Zhang, L.; Wang, Q.; Xiao, X.; Cai, S.; Chen, D.; Liu, H. Synthesis and infrared emissivity properties of novel polyurethane/Ag/ZnO array composite coatings. Infrared Phys. Technol. 2019, 102, 103049. [CrossRef]

78. Mishra, R.S.; Mishra, A.K.; Raju, K.V.S.N. Synthesis and property study of UV-curable hyperbranched polyurethane acrylate/ZnO hybrid coatings. Eur. Polym. J. 2009, 45, 960-966. [CrossRef]

79. Saeed, A.M.E.; Fattah, M.A.E.; Azzam, A.M. Synthesis of $\mathrm{ZnO}$ nanoparticles and studying its influence on the antimicrobial, anticorrosion and mechanical behavior of polyurethane composite for surface coating. Dyes Pigments 2015, 121, 282-289. [CrossRef]

80. Pavličević, J.; Špírková, M.; Bera, O.; Jovičić, M.; Pilić, B.; Baloš, S.; Simendić, J.B. The influence of ZnO nanoparticles on thermal and mechanical behavior of polycarbonate-based polyurethane composites. Compos. Part B Eng. 2014, 60, 673-679. [CrossRef]

81. Carmona, M.M.; Gun'ko, Y.; Regí, M.V. ZnO Nanostructures for drug delivery and theranostic applications. Nanomaterials 2018, 8, 268. [CrossRef]

82. Ambrožič, G.; Šribar, J.; Škapin, S.D.; Žigon, M.; Orel, Z.C. An antibacterial macroporous polyurethane hybrid material with a high content of zinc ions: A template to uniform ZnO. Mater. Res. Bull. 2013, 48, 1428-1434. 
83. Tijing, L.D.; Ruelo, M.T.G.; Amarjargal, A.; Pantc, H.R.; Park, C.-H.; Kim, D.W.; Kim, C.S. Antibacterial and superhydrophilic electrospun polyurethane nanocomposite fibers containing tourmaline nanoparticles. Chem. Eng. J. 2012, 197, 41-48. [CrossRef]

84. Farrokhi, Z.; Ayati, A.; Kanvisi, M.; Sillanpää, M. Recent advance in antibacterial activity of nanoparticles contained polyurethane. J. Appl. Polym. Sci. 2019, 136, 46997. [CrossRef]

85. Gu, X.; Chen, G.; Zhao, M.; Watson, S.S.; Nguyen, T.; Chin, J.W.; Martin, J.W. Critical role of particle/polymer interface in photostability of nano-filled polymeric coatings. J. Coat. Technol. Res. 2012, 9, 251-267. [CrossRef]

86. Miklecic, J.; Blagojevic, S.L.; Petric, M.; Rajkovic, V.J. Influence of $\mathrm{TiO}_{2}$ and $\mathrm{ZnO}$ nanoparticles on properties of waterborne polyurethane coating exposed to outdoor conditions. Prog. Org. Coat. 2015, 89, 67-74. [CrossRef]

87. Rashvand, M.; Ranjbar, Z.; Rastegar, S. Nano zinc oxide as a UV-stabilizer for aromatic polyurethane coatings. Prog. Org. Coat. 2011, 71, 362-368. [CrossRef]

88. Zhang, S.; Zhang, D.; Bai, H.; Ming, W. ZnO nanoparticles coated with amphiphilic polyurethane for transparent polyurethane nanocomposites with enhanced mechanical and UV-shielding performance. ACS Appl. Nano Mater. 2020, 3, 59-67. [CrossRef]

89. Amna, T.; Hassan, M.S.; Sheikh, F.A.; Lee, H.K.; Seo, K.S.; Yoon, D.; Hwang, I.H. Zinc oxide-doped poly(urethane) spider web nanofibrous scaffold via one-step electrospinning: A novel matrix for tissue engineering. Appl. Microbiol. Biotechnol. 2013, 97, 1725-1734. [CrossRef]

90. Mirmohseni, A.; Azizi, M.; Dorraji, M.S.S. A promising ternary nanohybrid of Copper@Zinc oxide intercalated with polyaniline for simultaneous antistatic and antibacterial applications. J. Coat. Technol. Res. 2019, 16, 1411-1422. [CrossRef]

91. Zvekić, D.; Srdić, V.V.; Karaman, M.A.; Matavulj, M.N. Antimicrobial properties of ZnO nanoparticles incorporated in polyurethane varnish. Process. Appl. Ceram. 2011, 5, 41-45. [CrossRef]

92. Pholnak, C.; Sirisathitkul, C.; Danworaphong, S.; Harding, D.J. Sono-synthesized sword-like zinc oxide and its use as a filler in polyurethane composites. J. Optoelectron. Adv. Mater. 2012, 14, 441-447.

93. Lee, S. Multifunctionality of layered fabric systems based on electrospun polyurethane/zinc oxide nanocomposite fibers. J. Appl. Polym. Sci. 2009, 114, 3652-3658. [CrossRef]

94. Yan, L.; Li, Q.; Chi, H.; Qiao, Y.; Zhang, T.; Zheng, F. One-pot synthesis of acrylate resin and ZnO nanowires composite for enhancing oil absorption capacity and oil-water separation. Adv. Compos. Hybrid Mater. 2018, 1, 567-576. [CrossRef]

95. William, J.K.M.; Ponmani, S.; Samuel, R.; Nagarajan, R.; Sangwai, J.S. Effect of CuO and ZnO nanofluids in xanthan gum on thermal, electrical and high pressure rheology of water-based drilling fluids. J. Pet. Sci. Eng. 2014, 117, 15-27. [CrossRef]

96. Singh, A.; Singh, N.B.; Afzal, S.; Singh, T.; Hussain, I. Zinc oxide nanoparticles: A review of their biological synthesis, antimicrobial activity, uptake, translocation and biotransformation in plants. J. Mater. Sci. 2018, 53, 185-201. [CrossRef]

97. Yang, L.H.; Liu, F.C.; Han, E.H. Effects of P/B on the properties of anticorrosive coatings with different particle size. Prog. Org. Coat. 2005, 53, 91-98. [CrossRef]

98. Dhoke, S.K.; Khanna, A.S.; Sinha, T.J.M. Sol-gel coatings on metals for corrosion protection. Prog. Org. Coat. 2009, 64, 371-382. [CrossRef]

99. Duarah, R.; Karak, N. High performing smart hyperbranched polyurethane nanocomposites with efficient self-healing, self-cleaning and photocatalytic attributes. New J. Chem. 2018, 42, 2167-2169. [CrossRef]

100. Koerner, H.; Kelley, J.; George, J.; Drummy, L.; Mirau, P.; Bell, N.S.; Hsu, J.W.P.; Vaia, R.A. ZnO Nanorod-Thermoplastic Polyurethane Nanocomposites: Morphology and Shape Memory Performance. Macromolecules 2009, 42, 8933-8942. [CrossRef]

101. Wang, Y.; Zhang, P.; Zhao, Y.; Dai, R.; Huang, M.; Liu, W.; Liu, H.; He, S.; Zhu, C. Shape memory composites composed of polyurethane/ZnO nanoparticles as potential smart biomaterials. Polym. Compos. 2020, 41, 2094-2107. [CrossRef]

102. Jiang, J.; Pi, J.; Cai, J. The advancing of zinc oxide nanoparticles for biomedical applications. Bioinorg. Chem. Appl. 2018, 2018, 1062562. [CrossRef]

103. Wang, X.; Liang, D.; Cheng, B. Preparation and research of intrinsic self-healing elastomers based on hydrogen and ionic bond. Compos. Sci. Technol. 2020, 193, 108127. [CrossRef] 
104. Wu, X.; Wang, J.; Huang, J.; Yang, S. Room temperature readily self-healing polymer via rationally designing molecular chain and crosslinking bond for flexible electrical sensor. J. Colloid Interface Sci. 2020, 559, $152-161$. [CrossRef] [PubMed]

105. Thangavel, G.; Tan, M.W.M.; Lee, P.S. Advances in self-healing supramolecular soft materials and nanocomposites. Nano Converg. 2020, 6, 29. [CrossRef] [PubMed] 